\title{
39. ACCUMULATION RATES AND COMPOSITION OF ORGANIC MATTER IN LATE CENOZOIC SEDIMENTS UNDERLYING THE ACTIVE UPWELLING AREA OFF PERU ${ }^{1}$
}

\author{
H. L. ten Haven, ${ }^{2}$ R. Littke, ${ }^{2}$ J. Rullkötter, ${ }^{2}$ R. Stein,${ }^{3}$ and D. H. Welte ${ }^{2}$
}

\begin{abstract}
Deep-sea sediment samples from three Ocean Drilling Program (ODP) Leg 112 sites on the Peru continental margin were investigated, using a number of organic geochemical and organic petrographic techniques, for amounts and compositions of the organic matter preserved. Preliminary results include mass accumulation rates of organic carbon at Site 679 and characteristics of the organic facies for sediments from Sites 679, 681, and 684.

Organic-carbon contents are high, with few exceptions. Particularly high values were determined in the Pliocene interval at Site $684(4 \%-7.5 \%)$ and in the early Pliocene to Quaternary section of Hole 679D (2\%-9\%). Older sediments at this site have distinctively lower organic-carbon contents $(0.2 \%-2.5 \%)$. Mass accumulation rates of organic matter at Site 679 are 0.02 to $0.07 \mathrm{~g} \mathrm{carbon} / \mathrm{cm}^{2} / \mathrm{k}$.y. for late Miocene to early Pliocene sediments and higher by a factor of 5 to 10 in the Quaternary sediments. The organic matter in all samples has a predominantly marine planktonic and bacterial origin, with minor terrigenous contribution. Organic particle sizes are strikingly small, so that only a minor portion is covered by visual maceral analysis.

Molecular organic-geochemical data were obtained for nonaromatic hydrocarbons, aromatic hydrocarbons (including sulfur compounds), alcohols, ketones, esters, and carboxylic acids. Among the total extractable lipids, long-chain unsaturated ketones from Prymnesiophyte algae strongly predominate among the gas chromatography (GC) amenable components. Steroids are major constituents of the ketone and free- and bound-alcohol fractions. Perylene is the most abundant aromatic hydrocarbon, whereas in the nonaromatic hydrocarbon fractions, long-chain $\mathrm{n}$-alkanes from higher land plants predominate, although the total terrigenous organic matter proportion in the sediments is small.
\end{abstract}

\section{INTRODUCTION}

During Leg 11210 sites were occupied on the continental margin of western South America between $9^{\circ}$ and $14^{\circ} \mathrm{S}$. Two primary objectives of this leg were to unravel the tectonic history of the continental margin and to study the evolution of the coastal upwelling system (Suess, von Huene, et al., 1988). The sediments deposited in the forearc basins off Peru not only contain the relic effects of vertical movements of the basement foundation of the Andes margin, but also the sedimentary expression of the oceanographic history of one of the major upwelling regimes in the world. Several of these forearc basins, such as the Salaverry, Trujillo, and Lima basins, have contrasting tectonic histories, especially since the late Miocene (e.g., Suess et al., 1987). For instance, this is expressed by a landward migration of upwelling centers in the Lima Basin between upper Miocene and Quaternary time, as revealed by benthic foraminifer assemblages (Suess, von Huene, et al., 1988). The Peru upwelling system is a classical example of coastal upwelling (e.g., Parrish, 1982; Thiede and Suess, 1983). These upwelling areas are characterized by high fertility of the surface-water masses, resulting in an enhanced primary productivity. Thus, sediments deposited under such an active upwelling area often have elevated (marine) organic-matter contents and can, therefore, become potential petroleum source rocks in the course of geologic evolution (Demaison and Moore, 1980).

\footnotetext{
${ }^{1}$ Suess, E., von Huene, R., et al., 1990. Proc. ODP, Sci. Results, 112: College Station, TX (Ocean Drilling Program).

2 Institut für Erdöl und Organische Geochemie, KFA Jülich, Postfach 1913, D-5170 Jülich, Federal Republic of Germany.

${ }^{3}$ Institut für Geowissenschaften und Lithosphärenforschung, Universität Giessen, Senckenbergstrasse 3, D-8300 Giessen, Federal Republic of Germany.
}

\section{PREVIOUS ORGANIC-GEOCHEMICAL STUDIES IN THE PERU UPWELLING AREA}

A wealth of organic geochemical data are available from studies of sediment trap and core samples, especially from the Chemistry Department of the Woods Hole Oceanographic Institution (e.g., Farrington et al., 1988; Gagosian et al., 1983a, 1983b; Repeta, 1989; Repeta and Gagosian, 1983, 1984, 1987; Volkman et al., 1983, 1987; Wakeham, 1985; Wakeham et al., 1983, 1984). All these data refer to samples collected around $15^{\circ} \mathrm{S}$. In addition, a detailed study of an interfacial sediment from $12^{\circ} \mathrm{S}$ was conducted by the Organic Geochemistry Group of the University of Bristol (Smith, 1984; Smith et al., 1982, 1983a, 1983b).

Repeta (1989) and Repeta and Gagosian $(1983,1984,1987)$ reported the identification and distribution of carotenoids and their degradation products in suspended matter, sediment trap material, zooplankton fecal pellets, and surface sediments. Carotenoids, like chlorophyll a, function as photosynthetic pigments in all species of marine phytoplankton. Studies have shown that, in addition to unknown sources, zooplanktonic crustaceans, diatoms, dinoflagellates, cryptomonads, and purple nonsulfur photosynthetic bacteria contribute to organic matter. However, the distribution of carotenoids in surface sediments has also been shown as totally different from their distribution in sediment trap material. Typical carotenoid biomarkers for diatoms and dinoflagellates were nearly absent in surface sediments, an observation that the authors attributed to rapid degradation because of the presence of labile 5,6-epoxides in these carotenoids. In this respect, note that Klok et al. (1984) estimated that the concentration of loliolide, one of the principal degradation products (Repeta, 1989), was $\sim 2 \%$ of the total organic matter of a diatomaceous ooze from the Walvis Bay upwelling area.

The studies of Wakeham and his coworkers (Wakeham, 1985; Wakeham et al., 1983, 1984) emphasized the distribution 


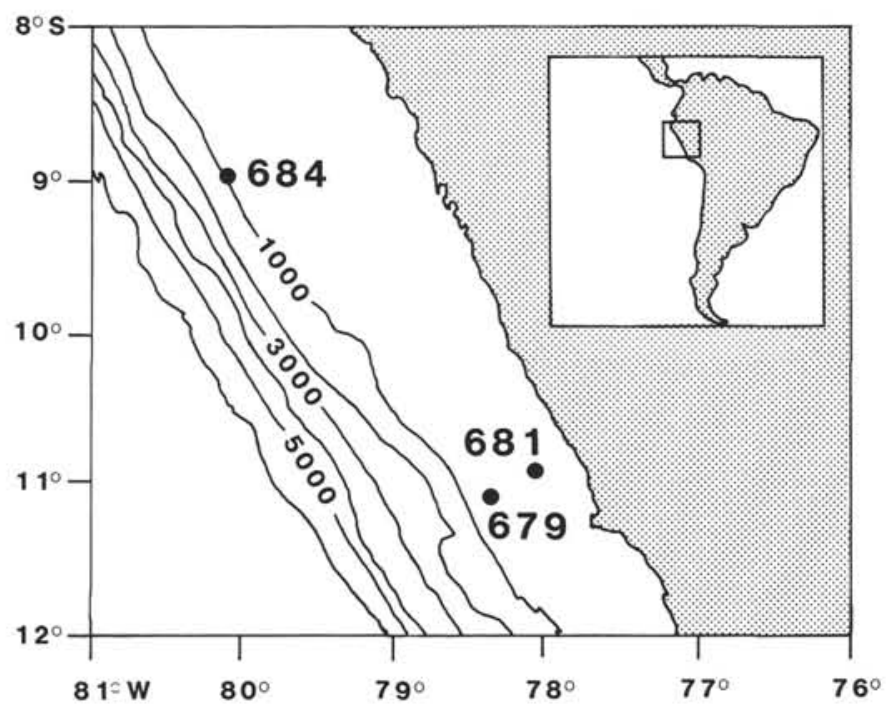

Figure 1. Location map of Sites 679, 681, and 684 of Leg 112 off the Peruvian coast.

of lipids, e.g., fatty acids, wax esters, and triacylglycerols, in particulate matter having a different size and from different depths and different geographic locations. Changes in the standing crop of primary producers were already noted during sampling: within a period of 4 days, a diatom bloom was replaced by a dinoflagellate bloom. The results indicate that the flux and composition of lipids is variable, even between daytime and nighttime.

The distribution of other classes of lipids, such as aliphatic hydrocarbons, sterols, long-chain ketones, and triterpenoid alcohols, was the focus of the research by Gagosian et al. (1983a, 1983b), Volkman et al. (1983, 1987), and Farrington et al. (1988). These studies included surface sediments. Typical hydrocarbons observed include $n$-alkanes, $\mathrm{C}_{37: 3}$ and $\mathrm{C}_{38: 3}$ alkenes, ${ }^{4}$ sterenes, and highly branched alkenes. Sterols from a variety of marine sources and long-chain unsaturated ketones were present in abundance (see also Cooper et al., 1986). The incorporation of many of these labile compounds into fast-sinking anchovy fecal pellets was proposed as a major mechanism of transport to the seafloor (cf. Staresinic et al., 1983). Triterpenoid alcohols of terrigenous and bacterial origin also were found.

In addition to several classes of lipids described above, Smith and his coworkers (Smith 1984; Smith et al., 1982, $1983 \mathrm{a}, 1983 \mathrm{~b})$ reported the presence of highly labile polyunsaturated fatty acids in a saponified extract from a surface sediment, indicating that little degradation or reworking of the lipids had occurred at that stage. They did not detect longchain alkandiols and alkan-15-on-1-ols (Smith et al., 1983c), although these compounds were found by Volkman et al. (1987; see also Farrimond et al., this volume).

This brief overview gives one an impression of the complexity of lipid sources and molecular sedimentary constituents in the Peru upwelling area.

\section{SAMPLES AND BACKGROUND INFORMATION}

This study detailing the amounts and compositions of organic matter deposited at Sites 679, 681 and 684 (Fig. 1) is based on core samples from Holes $679 \mathrm{C}, 681 \mathrm{C}$, and $684 \mathrm{C}$ dedicated to organic geochemistry (Table 1); all the recovered

\footnotetext{
${ }^{4} \mathrm{C}_{37: 3}$ denotes organic compounds with 37 carbon atoms and $3^{\circ}$ of unsaturation (double bonds or rings).
}

cores from these holes were deep-frozen on board the JOIDES Resolution immediately after collection. In addition, we analyzed a large number of samples from Hole 679D (Table 2) to monitor changes in organic- and carbonate-carbon accumulation during late Neogene and Quaternary time. The background information summarized next was taken from the respective site chapters of the Initial Reports of the Proceedings of the Ocean Drilling Program, Volume 112 (Suess, von Huene, et al., 1988).

Site 679 (Hole $679 \mathrm{C} ; 11^{\circ} 03.81^{\prime} \mathrm{S}, 76^{\circ} 16.33^{\prime} \mathrm{W}$, water depth of $461 \mathrm{~m}$ ) is located on the seaward flank of the structural ridge separating the Lima Basin from the Salaverry Basin. Sediments of middle Miocene to Holocene age extending to a maximum depth of 359.3 meters below seafloor (mbsf) were recovered at this site. The sequence has been divided into five lithologic units. The upper two units, which we studied, are classified on the basis of diatom and carbonate contents. Lithologic Unit I consists of diatomaceous foraminiferal mud, which is olive, olive gray, dark olive, dark gray or black, while Unit II is a diatomaceous mud having the same color gradation. Horizons containing phosphate nodules are common in all units. At the bottom of Hole $679 \mathrm{E}$ ( $350 \mathrm{mbsf}$ ), a dramatic increase in the concentration of thermogenic gas (ethane) was observed, and when combined with the petroliferous odor of the sediment, prompted Leg 112 scientists to abandon this site. However, a drilling-induced, artificial formation of the gas cannot be totally ruled out (see Suess, von Huene, et al., 1988, Site 679 chapter).

Site 681, located in the Salaverry Basin (Hole 681C; $10^{\circ} 58.60^{\prime} \mathrm{S}, 77^{\circ} 57.46^{\prime} \mathrm{W}$, water depth of $\left.161 \mathrm{~m}\right)$, is the most landward site and nearest to today's coastal upwelling centers. The water depth at this site nearly coincides with the top of the oxygen-minimum zone. The Quaternary sediment sequence that was penetrated to a maximum depth of $187 \mathrm{mbsf}$, has been divided into four lithologic units. Our sample suite is from the upper two units. Unit I primarily consists of dark olive-gray diatomaceous mud, with thin laminae of yellowbrown diatomaceous ooze. The distinctive laminated character is interrupted by an interval of bioturbated sediment between 12 and 15 mbsf. Unit II has a lower diatom content and a greater degree of bioturbation. Frequent sandy and silty beds represent a high proportion of this sequence.

Site 684 (Hole $684 \mathrm{C} ; 8^{\circ} 59.49^{\prime} \mathrm{S}, 79^{\circ} 54.35^{\prime} \mathrm{W}$, water depth of $437 \mathrm{~m}$ ) is located in the Trujillo Basin approximately $2^{\circ}$ north of Sites 679 and 681 . The penetrated sediment sequence of Miocene to Quaternary age (maximum depth 136.1 mbsf) was divided into five lithologic units. We received samples from the upper three units. Two hiatuses separate time-stratigraphic sections of late Quaternary, Pliocene, and Miocene age, respectively. Unit I was subdivided into two subunits, IA and IB; the former consists of dark olive diatomaceous mud and the latter of two sand beds separated by laminated diatomaceous mud. Unit II consists of black, silty or sandy, homogeneous to mottled, bioturbated mud almost devoid of diatoms. Unit III is characterized by dark olive-gray to black, homogeneous to mottled, bioturbated diatomaceous mud.

\section{EXPERIMENTAL METHODS}

Sediment samples were dried at $40^{\circ} \mathrm{C}$, and aliquots were impregnated with a resin for microscopic analyses. The surface of the block was ground and polished. Maceral composition was determined using a two-step counting procedure, both in reflected white light and in a fluorescence mode. Details of the analytical procedure are described elsewhere (Littke et al., 1988). Kerogen concentrates were prepared by treating samples with concentrated hydrochloric acid for $2 \mathrm{hr}$. 
Table 1. Depth intervals and bulk characteristics of the organic geochemistry samples.

\begin{tabular}{|c|c|c|c|c|c|c|}
\hline $\begin{array}{l}\text { Core, section, } \\
\text { interval }(\mathrm{cm})\end{array}$ & $\begin{array}{l}\text { Depth } \\
\text { (mbsf) }\end{array}$ & $\begin{array}{l}\text { Lithol. } \\
\text { unit }\end{array}$ & Age & $\underset{(\%)}{\mathrm{CaCO}_{3}}$ & $\begin{array}{l}\mathrm{C}_{\text {org }} \\
(\%)\end{array}$ & $\underset{\left(\mathrm{mg} \mathrm{HC} / \mathrm{g} \mathrm{C}_{\text {org }}\right)}{\mathrm{HI}}$ \\
\hline $112-679 \mathrm{C}-1 \mathrm{H}-1,30-37$ & 0.35 & I & Quaternary & 7.75 & 7.90 & 438 \\
\hline 679 C- $1 \mathrm{H}-6,133-140$ & 8.85 & I & Quaternary & 51.15 & 2.09 & 272 \\
\hline $679 \mathrm{C}-2 \mathrm{H}-4,30-37$ & 13.85 & I & Quaternary & 14.66 & 3.72 & 381 \\
\hline $679 \mathrm{C}-3 \mathrm{H}-4,30-37$ & 23.85 & I & Quaternary & 25.41 & 8.95 & 471 \\
\hline $679 \mathrm{C}-4 \mathrm{H}-4,30-37$ & 32.85 & I & Quaternary & 11.24 & 3.21 & 443 \\
\hline $679 \mathrm{C}-5 \mathrm{H}-4,30-37$ & 42.35 & I & Quaternary & 9.00 & 3.05 & 462 \\
\hline $679 \mathrm{C}-6 \mathrm{H}-4,30-37$ & 51.85 & II & Quaternary & 37.40 & 2.57 & 463 \\
\hline $679 \mathrm{C}-7 \mathrm{H}-4,30-37$ & 61.35 & II & Quat./Plio. & 23.82 & 2.68 & 713 \\
\hline $679 \mathrm{C}-8 \mathrm{H}-2,30-37$ & 67.85 & II & 1. Pliocene & n.d. & 7.52 & 446 \\
\hline $679 \mathrm{C}-8 \mathrm{H}-6,30-37$ & 73.85 & II & 1. Pliocene & 0.01 & 5.31 & 424 \\
\hline $681 \mathrm{C}-1 \mathrm{H}-1,30-37$ & 0.35 & I & Quaternary & 1.92 & 4.65 & 343 \\
\hline $681 \mathrm{C}-2 \mathrm{H}-1,30-37$ & 6.25 & I & Quaternary & 5.91 & 4.47 & 356 \\
\hline $681 \mathrm{C}-2 \mathrm{H}-6,5-12$ & 13.50 & I & Quaternary & 0.08 & 1.32 & 401 \\
\hline $681 \mathrm{C}-3 \mathrm{H}-4,30-36$ & 20.25 & I & Quaternary & 10.33 & 3.13 & 377 \\
\hline $681 \mathrm{C}-4 \mathrm{H}-4,30-36$ & 29.75 & I & Quaternary & 3.25 & 6.51 & 422 \\
\hline $681 \mathrm{C}-5 \mathrm{H}-4,32-38$ & 39.25 & II & Quaternary & 13.83 & 2.71 & 463 \\
\hline $681 \mathrm{C}-7 \mathrm{H}-4,30-37$ & 58.25 & II & Quaternary & 10.08 & 0.20 & 355 \\
\hline $681 \mathrm{C}-8 \mathrm{H}-4,30-37$ & 67.75 & II & Quaternary & 3.33 & 1.16 & 286 \\
\hline $681 \mathrm{C}-9 \mathrm{H}-4,30-37$ & 77.25 & II & Quaternary & 6.58 & 0.53 & 140 \\
\hline $681 \mathrm{C}-10 \mathrm{H}-4,30-37$ & 86.75 & II & Quaternary & 4.33 & 3.09 & 389 \\
\hline $684 \mathrm{C}-1 \mathrm{H}-1,30-37$ & 0.35 & IA & Quaternary & 8.91 & 3.56 & 339 \\
\hline $684 \mathrm{C}-1 \mathrm{H}-4,30-37$ & 4.85 & IA & Quaternary & 7.08 & 2.57 & 385 \\
\hline $684 \mathrm{C}-2 \mathrm{H}-4,30-37$ & 12.65 & IB & Quaternary & 50.40 & 0.86 & 240 \\
\hline $684 \mathrm{C}-3 \mathrm{H}-1,30-37$ & 17.65 & II/III & 1. Pliocene & n.d. & 6.21 & 269 \\
\hline $684 \mathrm{C}-3 \mathrm{H}-6,30-37$ & 25.15 & III & Pliocene & 0.01 & 5.89 & 380 \\
\hline $684 \mathrm{C}-4 \mathrm{H}-3,30-37$ & 30.15 & III & Pliocene & 11.33 & 7.46 & 395 \\
\hline $684 \mathrm{C}-4 \mathrm{H}-7,30-37$ & 36.15 & III & Pliocene & 4.91 & 4.09 & 387 \\
\hline
\end{tabular}

n.d. = not determined.

After careful washing and neutralization, residues were stirred with concentrated hydrofluoric acid for $16 \mathrm{hr}$ and subsequently washed neutral with distilled water (cf. Durand, 1980). The resulting powder was then prepared for maceral counting, as described above.

From a large set of kerogen concentrates of sediments from Hole 679D, the hydrogen and carbon contents were determined with a $\mathrm{CHN}$ analyzer to calculate atomic hydrogen/ carbon $(\mathrm{H} / \mathrm{C})$ ratios.

Sample-preparation techniques for organic geochemical studies, including carbon measurements, lipid extraction, compound class separation, derivatization, as well as instrumental conditions used for Rock-Eval analyses, gas chromatography (GC), and gas chromatography-mass spectrometry (GC-MS) were identical to those described in earlier studies of ODP samples (ten Haven and Rullkötter, 1988; ten Haven et al., 1989). However, in this study the esterification of acids was performed with diazomethane.

Compound identifications are based on comparison of relative GC retention times and mass spectra with those reported in the literature. The distribution of organic compounds is discussed in qualitative, rather than quantitative terms. Structures of selected compounds are given in the Appendix, and in the text these structures are referred to with Roman numerals.

\section{RESULTS AND DISCUSSION}

Depth, stratigraphic age, and bulk characteristics of the samples investigated are given in Tables 1 and 2. Results of carbonate, organic-carbon and Rock-Eval measurements show similar variations as data collected on board the ship (Suess, von Huene, et al., 1988). Carbonate values fluctuate from $0 \%$ to $66.2 \%$ (Tables 1 and 2 ; Fig. 2). The carbonate content may be primarily controlled by the presence or absence of calcareous plankton in discrete layers (Suess, von Huene, et al., 1988). Indeed, in the two samples having carbonate contents of more than $50 \%$ (Table 1) numerous foraminiferal tests were microscopically observed. Organic-

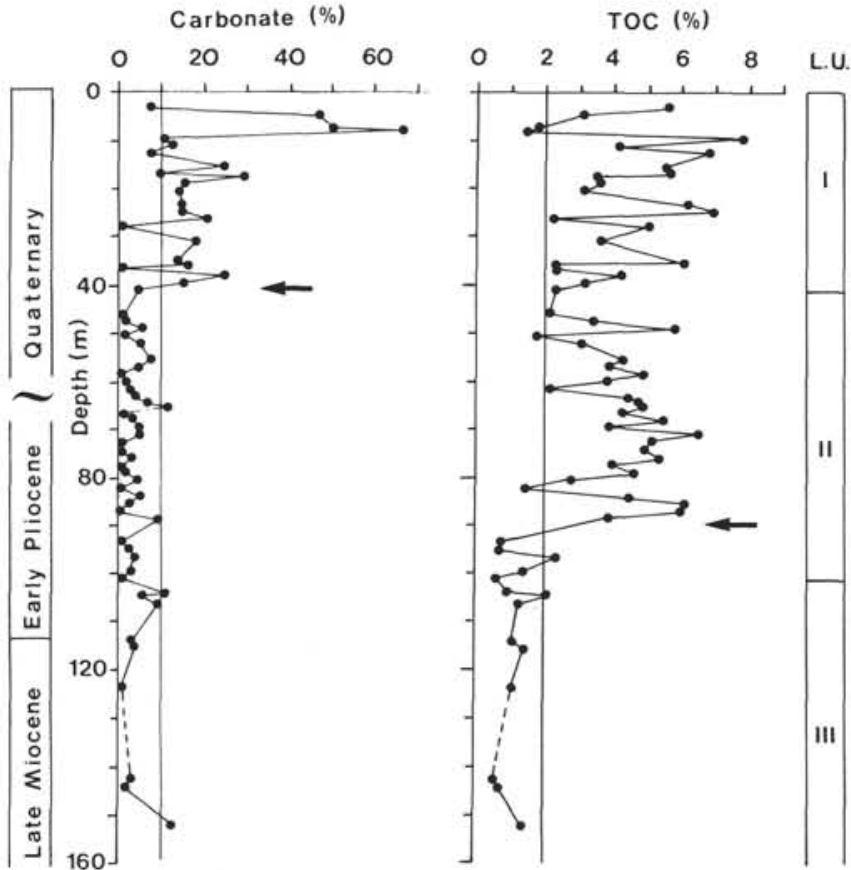

Figure 2. Organic and carbonate carbon records at Hole 679D (see Table 2). Arrows indicate the depth where major changes occur.

carbon contents are high, with the exception of Sample 112-681C-7H-4, 30-37 cm (Table 1). The more detailed organic-carbon record of Hole 679D can be divided into two parts (Fig. 2). The late Miocene and earliest Pliocene (lithologic Unit III) records are characterized by organic-carbon contents of $0.25 \%$ to $2.83 \%$, whereas the early Pliocene and Quaternary (lithologic Units I and II) records show distinctively higher values, ranging from $1.46 \%$ to $7.81 \%$. Note the high organic-carbon values of the Pliocene section of Site 684 
Table 2. Carbon contents of sediments and organic carbon and hydrogen data for kerogen concentrates of samples from Hole 679D.

\begin{tabular}{|c|c|c|c|c|c|c|c|}
\hline \multirow{2}{*}{$\begin{array}{l}\text { Core, section, } \\
\text { interval }(\mathrm{cm})\end{array}$} & \multirow[b]{2}{*}{ Depth (mbsf) } & \multirow[b]{2}{*}{$\mathrm{CaCO}_{3}(\%)$} & \multirow[b]{2}{*}{ C-tot $(\%)$} & \multirow[b]{2}{*}{ C-org (\%) } & \multicolumn{2}{|c|}{ Kerogen concentrates } & \\
\hline & & & & & $\mathrm{C}(\%)$ & $\mathrm{H}(\%)$ & $\mathrm{H} / \mathrm{C}$ (at) \\
\hline $112-679 \mathrm{D}-1 \mathrm{H}-1,19$ & 0.20 & & 11.50 & & 55.26 & 6.76 & 1.47 \\
\hline 679D-1H-2, 19 & 1.70 & & 11.25 & & & & \\
\hline 679D-1H-3, 19 & 3.20 & 7.2 & 6.52 & 5.65 & 40.78 & 5.28 & 1.55 \\
\hline 679D-1H-4, 19 & 4.70 & 46.9 & 8.73 & 3.10 & 55.10 & 6.56 & 1.43 \\
\hline 679D-1H-5, 19 & 6.20 & & & & 47.48 & 6.05 & 1.53 \\
\hline 679D-1H-6, 10 & 7.61 & 50.2 & 7.78 & 1.76 & 45.57 & 5.57 & 1.59 \\
\hline 679D-2H-1, 21 & 8.12 & 66.2 & 9.40 & 1.46 & 49.79 & 6.23 & 1.50 \\
\hline 679D-2H-2, 20 & 9.61 & 10.5 & 9.07 & 7.81 & 44.51 & 5.31 & 1.43 \\
\hline 679D-2H-3, 20 & 11.11 & 12.3 & 5.64 & 4.16 & & & \\
\hline 679D-2H-4, 21 & 12.62 & 7.5 & 7.71 & 6.81 & 47.88 & 6.07 & 1.52 \\
\hline 679D-2H-5, 20 & 14.11 & & 4.83 & & 52.68 & 6.99 & 1.59 \\
\hline 679D-2H-6, 20 & 15.61 & 24.7 & 8.52 & 5.55 & 56.15 & 6.34 & 1.35 \\
\hline 679D-2H-7, 18 & 17.09 & 9.6 & 6.81 & 5.66 & 55.41 & 6.82 & 1.48 \\
\hline 679D-3H-1, 19 & 17.60 & 29.4 & 7.08 & 3.55 & 54.65 & 6.83 & 1.50 \\
\hline 679D-3H-2, 19 & 19.10 & 15.3 & 5.48 & 3.64 & 55.24 & 6.70 & 1.46 \\
\hline $679 \mathrm{D}-3 \mathrm{H}-3,20$ & 20.61 & 14.3 & 4.86 & 3.15 & 55.77 & 6.67 & 1.43 \\
\hline $679 \mathrm{D}-3 \mathrm{H}-4,20$ & 22.11 & & 8.25 & & & & \\
\hline 679D-3H-5, 19 & 23.60 & 14.6 & 7.92 & 6.16 & 57.31 & 7.14 & 1.50 \\
\hline 679D-3H-6, 19 & 25.10 & 14.8 & 8.70 & 6.93 & 53.83 & 6.43 & 1.43 \\
\hline 679D-3H-7, 19 & 26.60 & 20.6 & 4.70 & 2.23 & 38.53 & & \\
\hline 679D-4H-1, 118 & 28.09 & 0.0 & 5.05 & 5.05 & 56.93 & 7.22 & 1.52 \\
\hline 679D-4H-2, 118 & 29.59 & & 10.96 & & 57.83 & 6.98 & 1.45 \\
\hline 679D-4H-3, 118 & 31.09 & 18.2 & 5.80 & 3.62 & 54.19 & 6.53 & 1.45 \\
\hline 679D-4H-6, 118 & 35.59 & 13.6 & 7.72 & 6.09 & & & \\
\hline $679 \mathrm{D}-4 \mathrm{H}-7,00$ & 35.91 & 16.1 & 4.21 & 2.28 & 45.62 & 5.93 & 1.56 \\
\hline 679D-5H-1, 20 & 36.61 & 0.5 & 2.38 & 2.32 & & & \\
\hline $679 \mathrm{D}-5 \mathrm{H}-2,20$ & 38.11 & 24.6 & 7.20 & 4.25 & 55.69 & 7.07 & 1.52 \\
\hline $679 \mathrm{D}-5 \mathrm{H}-3,20$ & 39.61 & 15.2 & 5.04 & 3.21 & 42.89 & 5.57 & 1.59 \\
\hline $679 \mathrm{D}-5 \mathrm{H}-4,20$ & 41.11 & 4.6 & 2.90 & 2.34 & 48.30 & 6.00 & 1.49 \\
\hline 679D-5H-5, 20 & 42.61 & & & 2.13 & & & \\
\hline $679 \mathrm{D}-6 \mathrm{H}-1,22$ & 46.13 & 0.9 & 2.27 & 2.16 & 51.21 & 6.51 & 1.52 \\
\hline 679D-6H-2, 22 & 47.63 & 1.4 & 3.61 & 3.44 & & & \\
\hline 679D-6H-3, 22 & 49.13 & 5.4 & 6.48 & 5.83 & 47.00 & 5.93 & 1.49 \\
\hline $679 \mathrm{D}-6 \mathrm{H}-4,22$ & 50.63 & 1.5 & 1.96 & 1.78 & 23.79 & 3.43 & 1.73 \\
\hline $679 \mathrm{D}-6 \mathrm{H}-5,24$ & 52.15 & 4.8 & 3.64 & 3.07 & 45.31 & 5.83 & 1.54 \\
\hline 679D-7H-1, 12 & 55.53 & 7.5 & 5.19 & 4.29 & 41.39 & 5.21 & 1.51 \\
\hline 679D-7H-2, 12 & 57.03 & 4.5 & 4.45 & 3.91 & 44.79 & 5.95 & 1.59 \\
\hline 679D-7H-3, 12 & 58.53 & 0.0 & 4.91 & 4.91 & 50.63 & 6.75 & 1.60 \\
\hline 679D-7H-4, 12 & 60.03 & 1.6 & 4.07 & 3.88 & 50.05 & 6.14 & 1.47 \\
\hline 679D-7H-5, 12 & 61.53 & 2.5 & 2.50 & 2.20 & 40.45 & 5.30 & 1.57 \\
\hline 679D-7H-6, 12 & 63.03 & 3.5 & 4.88 & 4.46 & 45.88 & 5.84 & 1.53 \\
\hline 679D-7H-7, 12 & 64.53 & 6.6 & 5.57 & 4.78 & & & \\
\hline 679D-8H-1, 22 & 65.13 & 11.7 & 6.34 & 4.93 & 49.42 & 6.77 & 1.64 \\
\hline 679D-8H-2, 22 & 66.63 & 0.6 & 4.42 & 4.35 & 53.31 & 6.52 & 1.47 \\
\hline 679D-8H-3, 22 & 68.13 & 3.1 & 5.90 & 5.53 & 48.91 & 6.73 & 1.65 \\
\hline 679D-8H-4, 22 & 69.63 & 4.8 & 4.49 & 3.92 & & & \\
\hline 679D-8H-5, 22 & 71.13 & 4.7 & 7.11 & 6.54 & 51.51 & 6.65 & 1.55 \\
\hline 679D-8H-6, 22 & 72.63 & 0.9 & 5.32 & 5.22 & 40.83 & 5.19 & 1.52 \\
\hline 679D-9H-1, 12 & 74.53 & 0.0 & 4.95 & 4.95 & 51.63 & 6.72 & 1.56 \\
\hline 679D-9H-2, 12 & 76.03 & 3.1 & 5.77 & 5.39 & 48.62 & 6.03 & 1.49 \\
\hline 679D-9H-3, 12 & 77.53 & 0.5 & 4.06 & 4.00 & 53.75 & 6.40 & 1.43 \\
\hline 679D-9H-4, 12 & 79.03 & 1.3 & 4.81 & 4.66 & & & \\
\hline 679D-9H-5, 12 & 80.53 & 4.4 & 3.36 & 2.84 & & & \\
\hline 679D-9H-6, 12 & 82.03 & 0.4 & 1.53 & 1.49 & 41.59 & 4.86 & 1.40 \\
\hline 679D-10H-1, 23 & 84.14 & 5.3 & 5.15 & 4.52 & 49.10 & 5.43 & 1.33 \\
\hline 679D-10H-2, 23 & 85.64 & 2.9 & 6.50 & 6.15 & & & \\
\hline 679D-10H-3, 23 & 87.14 & 0.0 & 6.02 & 6.01 & 42.54 & 5.32 & 1.50 \\
\hline 679D-10H-4, 23 & 88.64 & 9.4 & 5.06 & 3.94 & 40.05 & 5.02 & 1.50 \\
\hline 679D-11H-1, 20 & 93.61 & 0.0 & 0.78 & 0.78 & & & \\
\hline 679D-11H-2, 20 & 95.11 & 2.5 & 1.00 & 0.70 & & & \\
\hline 679D-11H-3, 20 & 96.61 & 3.7 & 2.83 & 2.39 & 37.11 & 4.67 & 1.51 \\
\hline $679 \mathrm{D}-11 \mathrm{H}-4,20$ & 98.11 & & 2.75 & & 43.54 & 5.32 & 1.47 \\
\hline $679 \mathrm{D}-11 \mathrm{H}-5,20$ & 99.61 & 2.6 & 1.71 & 1.40 & & & \\
\hline 679D-11H-6, 20 & 101.11 & 0.9 & 0.76 & 0.65 & & & \\
\hline 679D-12H-1, 20 & 103.11 & & & 0.25 & & & \\
\hline 679D-12H-2, 20 & 104.20 & 11.1 & 2.24 & 0.91 & 35.12 & 4.74 & 1.62 \\
\hline 679D-13X-1, 18 & 104.59 & 5.5 & 2.78 & 2.11 & 36.45 & 4.81 & 1.58 \\
\hline 679D-13X-2, 18 & 106.09 & 9.7 & 2.45 & 1.29 & & & \\
\hline 679D-14X-1, 18 & 114.09 & 3.2 & 1.50 & 1.12 & & & \\
\hline 679D-14X-2, 18 & 115.59 & 3.7 & 1.90 & 1.46 & & & \\
\hline 679D-15X-1, 20 & 123.61 & 0.0 & 1.08 & 1.08 & & & \\
\hline 679D-17X-1, 38 & 142.79 & 3.1 & 0.95 & 0.58 & & & \\
\hline 679D-17X-2, 38 & 144.29 & 1.7 & 0.91 & 0.71 & & & \\
\hline 679D-18X-1, 15 & 152.06 & 12.5 & 2.90 & 1.40 & & & \\
\hline 679D-18X-2, 15 & 153.56 & & 1.98 & & & & \\
\hline 679D-18X-3, 15 & 155.06 & & 1.62 & & & & \\
\hline
\end{tabular}


Table 3. Mean organic-carbon values and mass accumulation rates of total organic carbon at Hole 679D.

\begin{tabular}{|c|c|c|c|c|c|c|c|c|c|}
\hline \multirow[b]{2}{*}{ Cores } & \multirow[b]{2}{*}{ Depth (mbsf) } & \multirow[b]{2}{*}{ Age* } & \multirow[b]{2}{*}{$\mathrm{SR}^{*}$} & \multirow[b]{2}{*}{ WBD* } & \multirow[b]{2}{*}{$\mathrm{PO}^{*}$} & \multicolumn{2}{|c|}{ TOC } & \multicolumn{2}{|c|}{ MARTOC } \\
\hline & & & & & & Range & Mean & Range & Mean \\
\hline 1. $1 \mathrm{H}-7 \mathrm{H}$ & $0-64.9$ & Quaternary & 14 & 1.3 & 82 & $1.5-7.8$ & 4.0 & $0.10-0.50$ & 0.26 \\
\hline 2. $8 \mathrm{H}-10 \mathrm{H}$ & $64.9-93.4$ & e. Pliocene & 1.5 & 1.3 & 80 & $1.5-6.5$ & 4.7 & $0.01-0.05$ & 0.03 \\
\hline 3. $11 \mathrm{H}-13 \mathrm{X}$ & $93.4-113.9$ & e. Pliocene & 1.5 & 1.6 & 68 & $0.3-2.4$ & 1.2 & $0.004-0.03$ & 0.02 \\
\hline 4. $14 X-18 X$ & $113.9-161.4$ & 1. Miocene & 8 & 1.5 & 73 & $0.6-1.5$ & 1.1 & $0.04-0.09$ & 0.07 \\
\hline
\end{tabular}

$\mathrm{SR}=$ Mean sedimentation rate $(\mathrm{cm} / \mathrm{k} . \mathrm{y}.) ; \mathrm{WBD}=$ Wet bulk density $\left(\mathrm{g} / \mathrm{cm}^{3}\right) ; \mathrm{PO}=$ Porosity $(\%) ; \mathrm{TOC}=$ Total organic carbon $(\%)$; MARTOC $=$ Mass accumulation rates of total organic carbon $\left(\mathrm{gC}^{\mathrm{cm}} / \mathrm{k} . \mathrm{y}.\right)$.

*From Suess, von Huene, et al. (1988).

(Table 1); however, this phenomenon cannot be attributed simply to an intensification of upwelling because diagnostic diatom and coccolith upwelling assemblages are rare in lithologic Unit III (Suess, von Huene, et al., 1988, Site 684 chapter).

\section{Mass Accumulation Rates of Organic Carbon}

Changes in the percentages of organic carbon can result from changes in the supply of both mineral components and organic carbon. Hence, it is difficult to interpret an organiccarbon record, as shown in Figure 2 for Hole 679D. Therefore, the values were converted into mass accumulation rates (Table 3), following the equation developed by van Andel et al. (1975); MARTOC $=\mathrm{TOC} / 100 * \mathrm{SR} *(\mathrm{WBD}-1.025 \mathrm{PO} /$ 100), where MARTOC $=$ mass accumulation rate of total organic carbon $\left(\mathrm{g} / \mathrm{cm}^{2} / \mathrm{k} . \mathrm{y}.\right)$, TOC $=$ total organic carbon $(\%)$, $\mathrm{SR}=$ mean sedimentation rate $(\mathrm{cm} / \mathrm{k} . \mathrm{y}),. \mathrm{WBD}=$ wet bulk density $\left(\mathrm{g} / \mathrm{cm}^{3}\right)$, and $\mathrm{PO}=$ porosity $(\%)$. Using mass accumulation rates, dilution effects by inorganic components can be excluded, and the carbon data can be interpreted in terms of changes in supply or preservation of organic matter.

The mass accumulation rates of organic carbon were calculated for four time intervals at Hole 679D (Table 3). The late Miocene and early Pliocene intervals are characterized by low mean accumulation rates of 0.02 to $0.07 \mathrm{gC} / \mathrm{cm}^{2} / \mathrm{k}$.y. During Quaternary time, accumulation rates increased to an average value of $0.26 \mathrm{gC} / \mathrm{cm}^{2} / \mathrm{k}$.y. (range between 0.1 and 0.5 ). These latter rates are higher than the late Miocene and the early Pliocene values by factors of about 3 and 10 , respectively. Quaternary values are similar to those calculated for the same time interval in sediments from the Northwest African upwelling area (Site 658; Stein et al., in press). However, a comparison with the organic-carbon accumulation rates determined by Reimers and Suess (1983) for Holocene sediments from the Peru upper slope ( 0.5 to 6.3 $\mathrm{gC} / \mathrm{cm}^{2} / \mathrm{k}$.y.) shows that the Quaternary values at Hole 679D are relatively low. In the study of Reimers and Suess (1983), Holocene sedimentation rates could be determined much more accurately than was possible at Site 679 , due to the availability of ${ }^{210} \mathrm{~Pb}$ activity profiles. These sedimentation rates are as high as 30 to $1200 \mathrm{~cm} / \mathrm{k}$.y., resulting in the very high organic-carbon accumulation rates. Recalculation of the accumulation rates of organic carbon for the youngest interval of Site 679 may eventually lead to higher values, when better estimates of the sedimentation rates are available for this sequence.

The atomic $\mathrm{H} / \mathrm{C}$ ratios are about 1.5 (range 1.33 to 1.73 ) throughout the sediment sequence (Fig. 3; Table 2) and can be interpreted to indicate a dominantly marine origin of the organic matter. Such an origin is corroborated by high hydrogen-index (HI) values (Table 1) and the composition of the extractable lipids. Thus, the accumulation rates of total organic carbon represent the accumulation of marine organic carbon. In general, high amounts of marine organic carbon

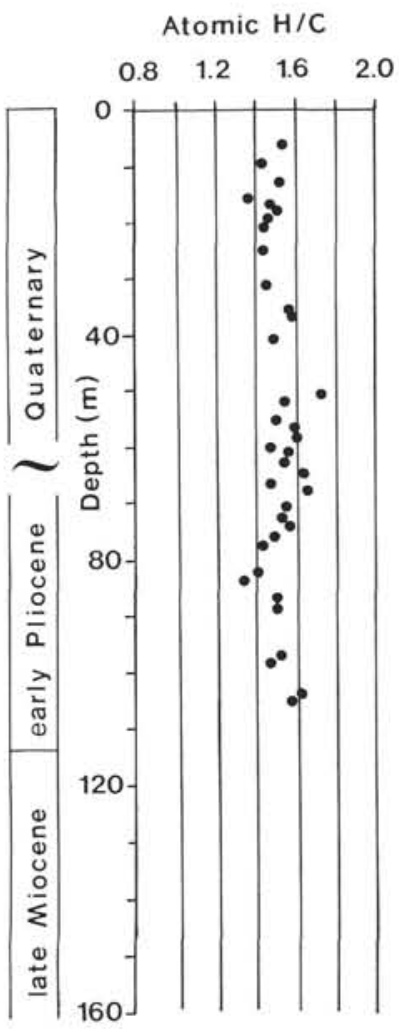

Figure 3. Atomic $\mathrm{H} / \mathrm{C}$ ratios of kerogen concentrates from sediments of Hole 679D (see Table 2).

can be accumulated in high-productivity (e.g., upwelling) areas and/or in oxygen-deficient environments, characterized by a high preservation rate of organic matter. According to the organic carbon/sedimentation rate diagram (Fig. 4), we suggest a distinct increase in paleoproductivity during Quaternary time as the major cause of the high content of marine organic carbon. Furthermore, high-amplitude variations in accumulation of organic carbon may imply short-term fluctuations in the magnitude of productivity, probably caused by changes in coastal upwelling intensity during Quaternary time (for a detailed study of these short-term, climate-induced changes in paleoproductivity, see Wefer and Suess, this volume).

The upper part of the early Pliocene at Hole 679D (interval 2 in Table 3) is characterized by high values of (marine) organic carbon and very low sedimentation rates (also low accumulation rates; Fig. 4). This may indicate special conditions leading to an enhanced preservation of organic matter, e.g., oxygen depletion in the water column from restricted circulation (cf. Stein, 1986). Thus, a large amount of marine organic matter could be preserved, although the sedimentation rate was very low. 


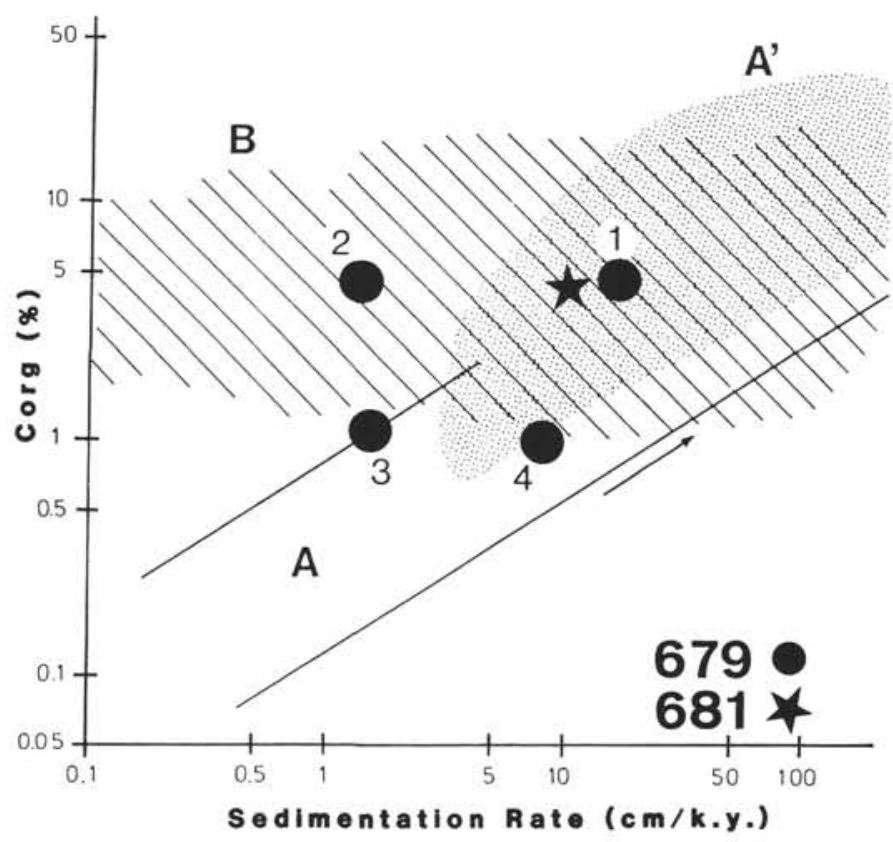

Figure 4. Organic carbon/sedimentation rate relationship (adapted from Stein, 1986). $\mathrm{A}=$ Open-marine oxic environment. $\mathrm{A}^{\prime}=$ High productivity field. $\mathrm{B}=$ Anoxic environment. Numbers 1 to 4 refer to Table 3.

\section{Organic Petrography}

Particles visible with a microscope (macerals in the organic-matter fraction of the sediments) include vitrinite, inertinite, and sporinite, all probably derived from higher land plants, as well as alginite, liptodetrinite, and large unstructured liptinite of marine origin. Alginites are defined here as brightly fluorescing, discoid particles that appear as long stripes in sections perpendicular to bedding. Liptodetrinites are defined as small fluorescing particles of irregular shape; most of these particles are probably related to alginite. Unstructured liptinites are large, brightly fluorescing particles sometimes occurring within fossil shells, e.g., in foraminifers. The bulk of the unstructured liptinites appear as ring-shaped particles having a diameter of less than $10 \mu \mathrm{m}$. The inner part of these particles generally is devoid of fluorescing material ("empty"). Relative percentages of the above-described macerals are listed in Table 4.

One of the most striking organic-matter characteristics in the sediments from the Peru upwelling area is the small particle size. Nearly all the alginites and liptodetrinites are smaller than $10 \mu \mathrm{m}$. With respect to the high organic-carbon values (Table 1) and the small percentages of detectable macerals in most samples, we conclude that the bulk of this organic matter is not visible by light microscopy, i.e., most organic particles are smaller than $1 \mu \mathrm{m}$. The size of vitrinites and inertinites depends on the fragmentation of organic clasts from higher land plants during transportation and potentially can be used as an indicator for the distance from land where the clasts originated (Stein et al., 1988). The size of vitrinites and inertinites in samples from Site 679 does not exceed 15 $\mu \mathrm{m}$. The average diameter increases slightly from the youngest Quaternary sediments toward the lower Pliocene section. Organic particles at Site 681 are up to $30 \mu \mathrm{m}$ in diameter throughout the whole section. The size of vitrinites and inertinites at Site 684 generally is less than $20 \mu \mathrm{m}$, but particles up to $80 \mu \mathrm{m}$ long occur in Sample 112-684C-2H-4, $30-37 \mathrm{~cm}$. The difference in size between organic clasts at Sites 679 and 681 probably reflects the distance from the coast (Fig. 1).

Because of the small percentage of organic matter that can be identified microscopically, the maceral composition is hardly reflected by bulk geochemical parameters. For instance, this is illustrated by a diagram showing the $\mathrm{HI}$ as a function of the relative amount of terrigenous macerals (Fig. 5 ). No negative correlation occurs between these two parameters, although organic matter of terrestrial origin is generally hydrogen-poor. However, such a correlation has been observed for other marine sediments in which most of the

Table 4. Percentages of identifiable macerals in the organic geochemistry samples.

\begin{tabular}{|c|c|c|c|c|c|c|c|}
\hline $\begin{array}{l}\text { Core, section, } \\
\text { interval }(\mathrm{cm})\end{array}$ & Vitr. & Inert. & Algin. & Li-detr. & unstr. Lipt. & Spor. & Remarks \\
\hline $112-679 \mathrm{C}-1 \mathrm{H}-1,30-37$ & 16 & 38 & 24 & 7 & 15 & 0 & \\
\hline $679 \mathrm{C}-1 \mathrm{H}-6,133-140$ & 15 & 38 & 7 & 1 & 37 & 0 & Foraminifers \\
\hline $679 \mathrm{C}-2 \mathrm{H}-4,30-37$ & 13 & 32 & 38 & 6 & 9 & 0 & Diatoms \\
\hline $679 \mathrm{C}-3 \mathrm{H}-4,30-37$ & 5 & 43 & 35 & 6 & 9 & 1 & \\
\hline $679 \mathrm{C}-4 \mathrm{H}-4,30-37$ & 0 & 54 & 20 & 5 & 21 & 0 & Diatoms \\
\hline $679 \mathrm{C}-5 \mathrm{H}-4,30-37$ & 8 & 56 & 24 & 2 & 10 & 0 & \\
\hline $679 \mathrm{C}-6 \mathrm{H}-4,30-37$ & 0 & 12 & 38 & 9 & 41 & 0 & \\
\hline $679 \mathrm{C}-7 \mathrm{H}-4,30-37$ & 0 & 0 & 48 & 10 & 41 & 0 & \\
\hline $679 \mathrm{C}-8 \mathrm{H}-2,30-37$ & 2 & 8 & 35 & 8 & 47 & 1 & \\
\hline $679 \mathrm{C}-8 \mathrm{H}-6,30-37$ & 6 & 15 & 6 & 4 & 68 & 0 & \\
\hline $681 \mathrm{C}-1 \mathrm{H}-1,30-37$ & 12 & 23 & 8 & 1 & 55 & 0 & \\
\hline $681 \mathrm{C}-2 \mathrm{H}-1,30-37$ & 7 & 13 & 60 & 5 & 14 & 0 & \\
\hline $681 \mathrm{C}-2 \mathrm{H}-6,5-12$ & 15 & 17 & 20 & 1 & 47 & 0 & \\
\hline $681 \mathrm{C}-3 \mathrm{H}-4,30-36$ & 25 & 34 & 31 & 6 & 3 & 0 & \\
\hline $681 \mathrm{C}-4 \mathrm{H}-4,30-36$ & 17 & 20 & 8 & 6 & 45 & 3 & Diatoms \\
\hline $681 \mathrm{C}-5 \mathrm{H}-4,32-38$ & 7 & 25 & 54 & 11 & 4 & 0 & \\
\hline $681 \mathrm{C}-7 \mathrm{H}-4,30-37$ & 12 & 24 & 3 & 1 & 60 & 0 & Coarse sedim. \\
\hline $681 \mathrm{C}-8 \mathrm{H}-4,30-37$ & 11 & 35 & 12 & 3 & 37 & 2 & \\
\hline $681 \mathrm{C}-9 \mathrm{H}-4,30-37$ & 24 & 38 & 3 & 1 & 34 & 0 & Coarse sedim. \\
\hline $681-10 \mathrm{H}-4,30-37$ & 24 & 40 & 7 & 3 & 26 & 0 & \\
\hline $684 \mathrm{C}-1 \mathrm{H}-1,30-37$ & 0 & 28 & 13 & 0 & 56 & 2 & \\
\hline $684 \mathrm{C}-1 \mathrm{H}-4,30-37$ & 15 & 42 & 4 & 2 & 36 & 0 & \\
\hline $684 \mathrm{C}-2 \mathrm{H}-4,30-37$ & 23 & 50 & 0 & 0 & 26 & 0 & Foraminifers \\
\hline $684 \mathrm{C}-3 \mathrm{H}-1,30-37$ & 15 & 28 & 16 & 9 & 31 & 0 & \\
\hline $684 \mathrm{C}-3 \mathrm{H}-6,30-37$ & 4 & 20 & 14 & 15 & 45 & 2 & Diatoms \\
\hline $684 \mathrm{C}-4 \mathrm{H}-3,30-37$ & 5 & 38 & 13 & 17 & 25 & 0 & \\
\hline $684 \mathrm{C}-4 \mathrm{H}-7,30-37$ & 8 & 54 & 12 & 6 & 20 & 0 & \\
\hline
\end{tabular}




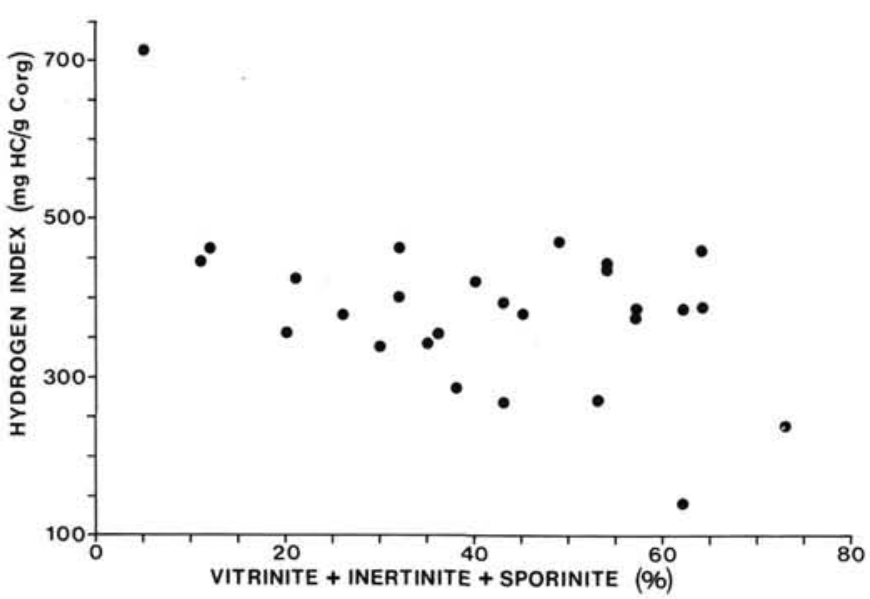

Figure 5. Cross plot of relative percentage of continent-derived macerals (vitrinite, inertinite, sporinite) vs. hydrogen index (HI) of organic matter.

organic matter is visible microscopically (e.g., Rullkötter et al., 1984; Stein et al., 1986). The high H/C ratios (Fig. 3; Table 2) point to a dominance of marine organic matter at Site 679. Clearly, volume percentages of pyrite are higher than those of total macerals. The ratio of pyrite to macerals exceeds ratios often observed in other marine black shales (e.g., Littke and Rullkötter, 1987). We interpret this as further supporting evidence for the hypothesis that most of the organic material is submicroscopically small.

A particular clue to the nature and mode of occurrence of the organic matter in samples from Leg 112 was obtained through the kerogen separation procedure using hydrochloric and hydrofluoric acid. Several samples were hardly affected by this procedure, i.e., little mass was lost and the residue contained not much more organic carbon than the starting material. This may be because finely disseminated organic matter impregnates some of the calcite and silicate particles and thus protects them from being destroyed by the acids.

\section{Lipid Geochemistry}

A total of 27 sediment samples (Table 1) were extracted, and these extracts divided into two parts. After derivatization, one part, the so-called total lipid fraction, was directly analyzed using GC and GC-MS. The other part was separated by medium pressure liquid chromatography (MPLC) into nonaromatic hydrocarbons, aromatic hydrocarbons, and heterocompounds. The heterocompound fractions of 14 samples were separated further by MPLC into alcohol, ester plus ketone, acid, base, and highly polar fractions. The alcohol, ester plus ketone, and acid fractions and, in one case, the highly polar fraction were analyzed using GC and GC-MS after appropriate derivatization. Extract yields and relative abundances of these compound classes, based on liquid chromatography, are given in Table 5. The compound classes are discussed separately, followed by a discussion of the total lipid fraction.

\section{Nonaromatic Hydrocarbon Fraction}

This class of compounds is mainly composed of a series of $n$-alkanes that range from $n-\mathrm{C}_{14}$ to $n-\mathrm{C}_{36}$ and show a strong odd-over-even carbon number preference of the higher homologs, with $n-C_{31}$ as the most abundant alkane. Such a distribution is characteristic of terrigenous organic matter (Eglinton and Hamilton, 1963), but the nonaromatic hydrocarbon fraction alone cannot be used to estimate the relative amount of terrigenous organic matter in the sediments because other biogenic sources do not contribute major quantities of $n$-alkanes (cf., ten Haven et al., 1989).

Among the polycyclic nonaromatic hydrocarbons, sterenes, steradienes $\left(\mathrm{C}_{27}\right.$ dominating; I, II), hop-17(21)-ene (III), $17 \beta(\mathrm{H}), 21 \beta(\mathrm{H})$-homohopane (IV) and fern-7-ene (V) are ubiquitously present. The former two groups of compounds

Table 5. Extract yields and relative abundance of compound classes.

\begin{tabular}{|c|c|c|c|c|c|c|c|c|c|}
\hline $\begin{array}{l}\text { Core, section, } \\
\text { interval }(\mathrm{cm})\end{array}$ & $\begin{array}{c}\text { Extract } \\
\text { (mg/g C }\end{array}$ & $\begin{array}{l}\text { N. arom. } \\
(\%)\end{array}$ & $\begin{array}{l}\text { Arom. } \\
(\%)\end{array}$ & $\begin{array}{c}\text { Hetero } \\
(\%)\end{array}$ & $\begin{array}{c}\text { Ketone } \\
(\%)\end{array}$ & $\begin{array}{c}\text { Alcohol } \\
(\%)\end{array}$ & $\begin{array}{l}\text { Acid } \\
(\%)\end{array}$ & $\begin{array}{l}\text { Base } \\
(\%)\end{array}$ & $\begin{array}{l}\text { H. polar } \\
(\%)\end{array}$ \\
\hline $112-679 \mathrm{C}-1 \mathrm{H}-1,30-37$ & 77 & 8 & 3 & (89) & 15 & 12 & 2 & 5 & 55 \\
\hline $679 \mathrm{C}-1 \mathrm{H}-6,133-140$ & 19 & 9 & 4 & 87 & & & -n.d.- & & \\
\hline $679 \mathrm{C}-2 \mathrm{H}-4,30-37$ & 59 & 2 & 2 & (96) & 13 & 8 & 11 & 6 & 58 \\
\hline $679 \mathrm{C}-3 \mathrm{H}-4,30-37$ & 48 & 4 & 2 & 94 & & & -n.d.- & & \\
\hline $679 \mathrm{C}-4 \mathrm{H}-4,30-37$ & 75 & 4 & 2 & (94) & 35 & 20 & 7 & 14 & 18 \\
\hline $679 \mathrm{C}-5 \mathrm{H}-4,30-37$ & 54 & 5 & 1 & 94 & & & -n.d.- & & \\
\hline $679 \mathrm{C}-6 \mathrm{H}-4,30-37$ & 42 & 1 & 2 & (97) & 19 & 7 & 7 & 8 & 56 \\
\hline $679 \mathrm{C}-7 \mathrm{H}-4,30-37$ & 54 & 12 & 6 & 82 & & & -n.d.- & & \\
\hline $679 \mathrm{C}-8 \mathrm{H}-2,30-37$ & 48 & 5 & 2 & (93) & 16 & 10 & 4 & 5 & 58 \\
\hline $679 \mathrm{C}-8 \mathrm{H}-6,30-37$ & 54 & 4 & 1 & 95 & & & -n.d.- & & \\
\hline $681 \mathrm{C}-1 \mathrm{H}-1,30-37$ & 76 & 3 & 1 & (96) & 16 & 11 & 5 & 26 & 38 \\
\hline $681 \mathrm{C}-2 \mathrm{H}-1,30-37$ & 43 & 4 & 2 & 94 & & & - n.d. - & & \\
\hline $681 \mathrm{C}-2 \mathrm{H}-6,5-12$ & 16 & 13 & 3 & (84) & 14 & 8 & 3 & 18 & 41 \\
\hline $681 \mathrm{C}-3 \mathrm{H}-4,30-36$ & 12 & 6 & 2 & 92 & & & -n.d.- & & \\
\hline $681 \mathrm{C}-4 \mathrm{H}-4,30-36$ & 14 & 2 & 3 & (95) & 22 & 13 & 3 & 21 & 36 \\
\hline $681 \mathrm{C}-5 \mathrm{H}-4,32-38$ & 15 & 3 & 1 & 96 & & & -n.d.- & & \\
\hline $681 \mathrm{C}-7 \mathrm{H}-4,30-37$ & 42 & 2 & 1 & (97) & 6 & 1 & 2 & 31 & 57 \\
\hline $681 \mathrm{C}-8 \mathrm{H}-4,30-37$ & 13 & 2 & 4 & 94 & & & -n.d.- & & \\
\hline $681 \mathrm{C}-9 \mathrm{H}-4,30-37$ & 12 & 5 & 2 & (93) & 10 & 6 & 5 & 31 & 41 \\
\hline $681 \mathrm{C}-10 \mathrm{H}-4,30-37$ & 18 & 5 & 2 & 93 & & & - n.d.- & & \\
\hline $684 \mathrm{C}-1 \mathrm{H}-1,30-37$ & 17 & 6 & 1 & (93) & 10 & 5 & 3 & 36 & 39 \\
\hline $684 \mathrm{C}-1 \mathrm{H}-4,30-37$ & 14 & 4 & 1 & 95 & & & -n.d.- & & \\
\hline $684 \mathrm{C}-2 \mathrm{H}-4,30-37$ & 18 & 4 & 1 & (95) & 15 & 3 & 13 & 37 & 27 \\
\hline $684 \mathrm{C}-3 \mathrm{H}-1,30-37$ & 12 & 5 & 2 & 93 & & & -n.d. - & & \\
\hline $684 \mathrm{C}-3 \mathrm{H}-6,30-37$ & 12 & 7 & 2 & (91) & 23 & 10 & 5 & 9 & 44 \\
\hline $684 \mathrm{C}-4 \mathrm{H}-3,30-37$ & 11 & 4 & 3 & 93 & & & -n.d.- & & \\
\hline $684 \mathrm{C}-4 \mathrm{H}-7,30-37$ & 14 & 8 & 2 & (90) & 21 & 12 & 3 & 25 & 29 \\
\hline
\end{tabular}

Note: Relative abundances are normalized to $100 \%$, hence loss of material during work-up procedures was not taken into account. This loss is most pronounced for the highly polar fraction. $\mathrm{n} . \mathbf{d}$. $=$ not determined. 


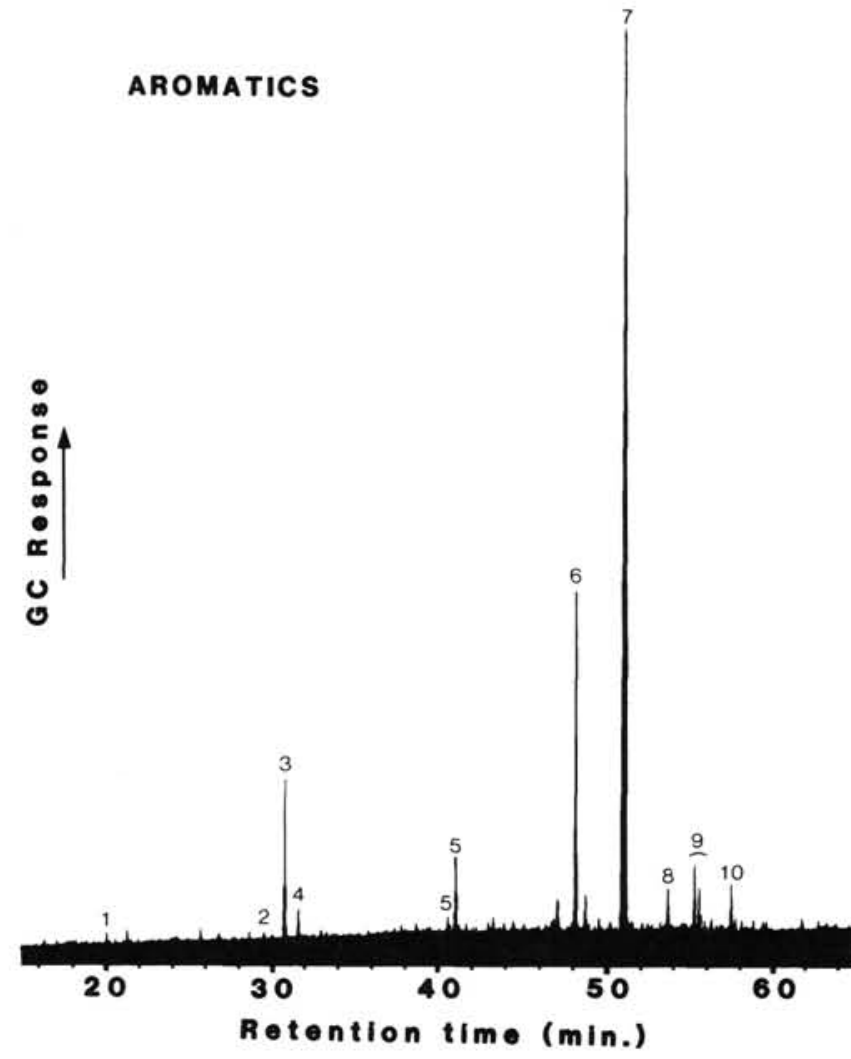

Figure 6. Partial gas chromatogram of the "aromatic hydrocarbon" fraction of Sample 112-684C-4H-7, 30-37 cm. Identification of numbered compounds is given in Table 6.

are derived from algae/phytoplankton sources (e.g., Volkman, 1986), while the latter three groups presumably have a bacterial origin (e.g., Brassell et al., 1981; Ourisson et al., 1984). In addition, a compound with a molecular ion at $\mathrm{m} / \mathrm{z} 368$ and characteristic fragments at $\mathrm{m} / \mathrm{z} 147$ and 191 is present in all samples. We have tentatively identified this compound as a trisnorhopene.

Interestingly, no traces of the highly branched $\mathrm{C}_{20^{-}}$and $\mathrm{C}_{25}$-alkenes were observed, potential biological markers of diatoms (Nichols et al., 1988), although these compounds are present in high abundance in surface sediments at $15^{\circ} \mathrm{S}$ (Volkman et al., 1983; Farrington et al., 1988). However, these authors noted a strong decrease in concentration with depth (within $30 \mathrm{~cm}$ ) of these labile compounds, which may explain their absence in our samples. A possible sink for these compounds is a reaction with $\mathrm{H}_{2} \mathrm{~S}$ or polysulfides with the formation of the sulfur-bearing derivatives (Sinninghe Damsté et al., 1989).

\section{Aromatic Hydrocarbon Fraction}

An example of a gas chromatogram of the aromatic hydrocarbon fraction of a sediment extract from Site 684 is given in Figure 6. The identified compounds are listed in Table 6. Perylene (7; VI), a pentacyclic aromatic hydrocarbon is the most abundant compound in most of the samples studied. The precursor of this compound is still a matter of debate, but must be omnipresent, judging from the widespread occurrence of perylene in the geosphere. Preliminary quantitative results indicate that its concentration increases with depth, which is in accordance with the suggestion that perylene is formed during early diagenesis under reducing conditions (see Gschwend et al., 1983, and references therein). A methylated
Table 6. Compounds identified in the aromatic hydrocarbon fraction of Sample 112-684C-4H-7, 30-37 cm (Fig. 6).

\begin{tabular}{llrc}
\hline & M & BP & Struct.* \\
\hline $\begin{array}{llrl}\text { 1. 2-ethyl-5-decyl-thiophene or isoprenoid } \\
\text { thiophene }\end{array}$ & 252 & 125 & \\
2. 2-methyl-5-tridecyl-thiophene & 280 & 111 & \\
3. 3-methyl-2-(3,7,11-trimethyldodecyl)- & 308 & 111 & VIII \\
$\quad$ thiophene & & & \\
4. 3-(4,8,12-trimethyltridecyl)-thiophene & 308 & 98 & IX \\
5. monocyclic disulfides** & 344 & 57 & \\
6. monocyclic trisulfide** & 376 & 57 & \\
7. perylene & 252 & 252 & VI \\
8. 2-methylperylene & 266 & 266 & \\
9. B-ring monoaromatic $14 \beta(\mathrm{H})-\mathrm{C}_{27}$ & 366 & 211 & VII \\
anthrasteroid & & & \\
10. B-ring monoaromatic $\Delta^{\mathrm{N}-} \mathrm{C}_{28}$ anthrasteroid & 378 & 211 & \\
& & &
\end{tabular}

*See Appendix for molecular structures.

${ }^{* *}$ Tentative identification.

perylene (8) was also present, and the methyl group is most likely located at position 2 of the aromatic ring system (Garrigues et al., 1988). Other aromatic hydrocarbons include $\mathrm{C}_{27}$ (9; VII), $\mathrm{C}_{28}$ and $\mathrm{C}_{29}$ B-ring monoaromatic anthrasteroids ( $\mathrm{C}_{27}$ dominating). The $\mathrm{C}_{27}$ member also was found by Farrington et al. (1988) in a surface sediment from the Peru margin at $15^{\circ} \mathrm{S}$. Compound 10 presumably is a $\mathrm{C}_{28}$ B-ring aromatic anthrasteroid with an additional double bond. The mass spectrum of this compound is presented in Figure 7A and shows the typical fragment ions of a $\mathrm{C}_{28}$ B-ring aromatic anthrasteroid, but the molecular ion and the common key fragment at $\mathrm{m} / \mathrm{z} 251$ have been shifted by two daltons to lower values, indicating the presence of an additional double bond.

The remainder of the aromatic hydrocarbon fraction is composed of several organic sulfur compounds, of which two $\mathrm{C}_{20}$ isoprenoid thiophenes $(3,4$; VIII, IX) and an unknown sulfur compound (6) are most abundant. Isoprenoid thiophenes have been found in numerous marine sediments and are presumed to be diagenetic products of early sulfur incorporation into chlorophyll-derived phytol, or into diagenetic transformation products of phytanyl moieties from archaebacteria (Brassell et al., 1986; Rullkötter et al., 1988; in press). Several sulfur compounds (e.g., 5) with as yet unknown structures are present. These compounds have a molecular ion at $\mathrm{m} / \mathrm{z} 330+14 n(n=0,1,2)$. All these compounds show a characteristic fragment of $\mathrm{M}^{+}-33\left(\mathrm{M}^{+}-\mathrm{SH}\right)$ and, based on the response of the sulfur-selective flame photometric detector (FPD), they contain two sulfur atoms. Thus, the elemental composition is $\mathrm{C}_{\mathrm{n}} \mathrm{H}_{2 \mathrm{n}} \mathrm{S}_{2}(n=19,20,21)$, which can be tentatively ascribed to alkyl- or isoprenoid monocyclic disulfides. In this respect, one should mention that Ciereszko and Youngblood (1971) reported the presence of $n$-hexadecyl and $n$-octadecyl disulfides ( $\left.\mathrm{R}^{\prime}-\mathrm{S}-\mathrm{S}-\mathrm{R}\right)$ in an artificially prepared sediment from the gorgonian Pseudoplexaura porosa. The mass spectrum of the most abundant unkown compound (6) is presented in Figure 7B. The molecular ion of $\mathrm{m} / \mathrm{z} 376$, and the ions at $\mathrm{m} / \mathrm{z} 344\left(\mathrm{M}^{+}-\mathrm{S}\right)$, and $\mathrm{m} / \mathrm{z} 311$ (344-SH), combined with the response signal of the FPD, indicate that we are dealing with an alkyl- or isoprenoid monocyclic trisulfide. The structural elucidation of these novel organic sulfur compounds is the subject of current investigation in collaboration with the Organic Geochemistry Unit of the Delft University of Technology (The Netherlands).

In a few samples, traces of two isomeric highly branched isoprenoid $\mathrm{C}_{25}$ thiophenes $(\mathrm{X})$ were observed; these may result when sulfur is incorporated into corresponding olefinic dienes. These compounds have been proposed as potential 


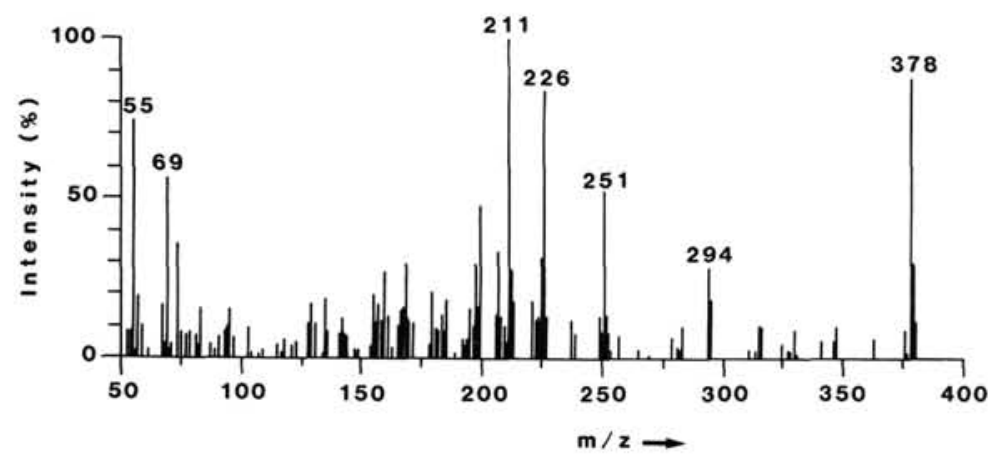

A
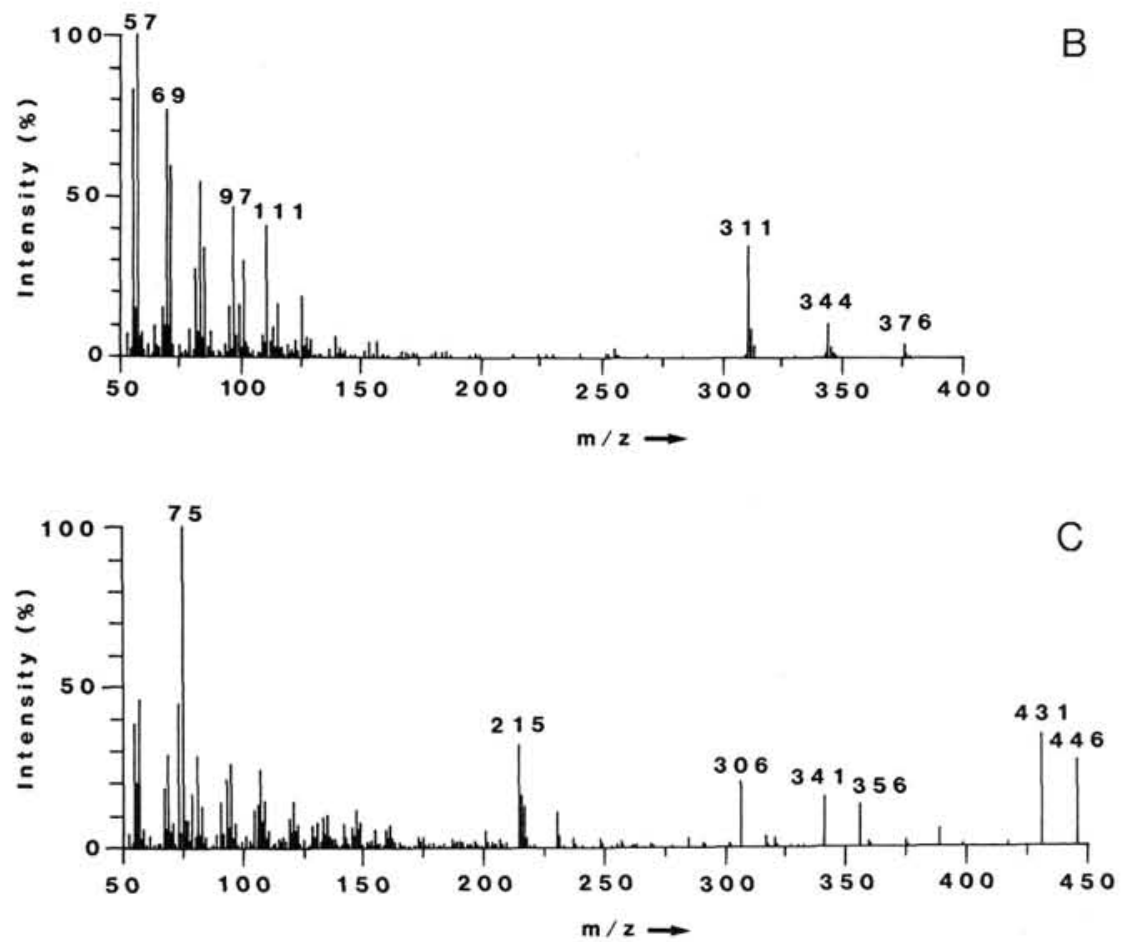

Figure 7. Mass spectra of compounds tentatively identified as (A) $\Delta^{n}-C_{28}$ anthrasteroid, (B) monocyclic trisulfide, and (C) 24 -nor- $5 \alpha(\mathrm{H})$-cholestan-3 $\beta$-ol.

biomarkers for diatoms (Sinninghe Damsté et al., 1989). They were observed as the most important compounds of the aromatic hydrocarbon fraction of various deep-sea sediments (Rullkötter et al., in press), and thus, their low abundance in the Peru margin sediments, despite the abundance of diatoms, is puzzling. Volkman et al. (1983) described the presence of highly branched alkenes in surface sediments from the Peruvian upwelling. Most of these compounds were trienes, and perhaps the double bonds were not in the right position to result in $\mathrm{C}_{25}$ thiophenes. An alternative explanation is that the sulfur compounds are present in the heterocompound fraction, cross-linked to higher-molecular-weight substances and only liberated during a later stage of diagenesis.

\section{Carboxylic Acid Fraction}

Saturated straight-chain $\mathrm{C}_{16}$ and $\mathrm{C}_{18}$ fatty acids, which have no diagnostic value because of their widespread occurrence in the biosphere, are the most abundant compounds here. Longer straight-chain fatty acids $\left(\mathrm{C}_{20}-\mathrm{C}_{26}\right)$, maximizing at $\mathrm{C}_{22}$, are present in trace amounts. No unsaturated or polyunsaturated fatty acids were observed, although such compounds were found by Smith et al. (1983a, 1983b) and Wakeham et al.
(1983) in a surface sediment and in particulate matter, respectively. These authors saponificated the extract before the isolation of the acid fraction, and, hence, the mode of occurrence of these unsaturated fatty acids (e.g., free or esterified) is not known. Moreover, such compounds are highly labile, and, therefore, their absence in the extractable lipids of older deep-sea sediments is not surprising.

\section{Ketone and Ester Fraction}

The most important compounds of this fraction are $\mathrm{C}_{37}(3$, 4 ; $\mathrm{XI}$ ) and $\mathrm{C}_{38}(5,6,8,9)$ di- and triunsaturated ketones (Fig. 8; Table 7), for which an origin from Prymnesiophyte algae (especially Emiliania huxleyi in late Quaternary sediments) has been presumed (e.g., Volkman et al., 1980; Marlowe et al., 1984). Other components are $\mathrm{C}_{39}$ unsaturated ketones (10, 11), 6,10,14-trimethylpentadecan-2-one (not shown in Fig. 8), hopanoid ketones (7; XIII), and a variety of steroid ketones, including $\mathrm{C}_{2}-\mathrm{C}_{29}$ steran-3-ones, cholesta-3,5-dien-7-one, $\mathrm{C}_{28}$ $\mathrm{C}_{30} 4$-methylsteran-3-ones, and $4 \alpha, 23,24$-trimethylcholest-22en-3-one (1; XIV; dinosterone). All these compounds originated from marine planktonic organisms, with the exception of the hopanoid ketones, which can be assigned to a bacterial 


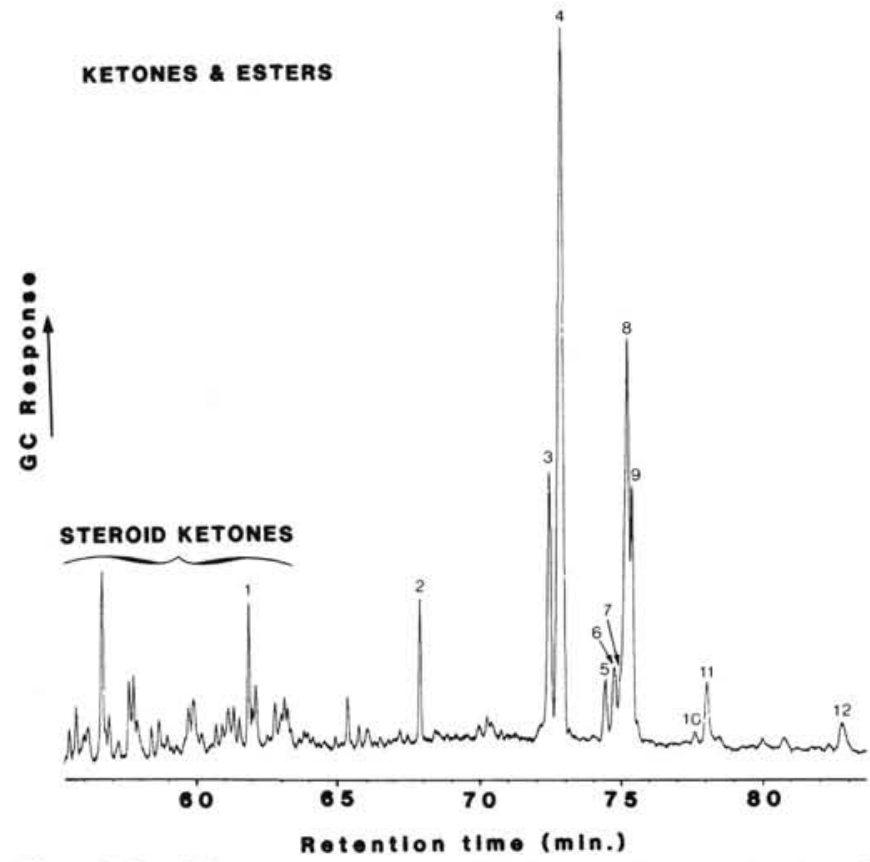

Figure 8. Partial gas chromatogram of the ketone plus ester fraction of Sample 112-681C-1H-1, 30-37 cm. Identification of numbered compounds is given in Table 7.

Table 7. Compounds identified in the ketone plus ester fraction of Sample 112-681C-1H-1, 30-37 cm (Fig. 8).

\begin{tabular}{|c|c|c|c|}
\hline & $\mathrm{M}+$ & BP & Struct.* \\
\hline \multirow{2}{*}{$\begin{array}{l}\text { 1. 4 } \alpha, 23,24 \text {-trimethylcholest-22-en-3-one } \\
\text { (dinosterone) or } 4 \alpha \text {-methyl,24- } \\
\text { ethylcholest-22-en-3-one }\end{array}$} & 426 & 69 & \multirow[t]{2}{*}{ XIV } \\
\hline & 426 & 69 & \\
\hline 2. $17 \beta(\mathrm{H}), 21 \beta(\mathrm{H})$-hopan-30-oic methylester & 456 & 235 & $\mathrm{XV}$ \\
\hline 3. heptatriaconta-8(E),15(E),22(E)-trien-2-one & 528 & 55 & XI \\
\hline 4. heptatriaconta-15(E),22(E)-dien-2-one & 530 & 55 & \\
\hline \multirow{2}{*}{$\begin{array}{l}\text { 5. cluster of } C_{38} \text { diunsaturated wax esters** } \\
\text { and octatriaconta-9(E),16(E),23(E)- } \\
\text { trien-3-one }\end{array}$} & 560 & 55 & \multirow{9}{*}{ XIII } \\
\hline & 542 & 55 & \\
\hline 6. octatriaconta-9(E),16(E),23(E)-trien-2-one & 542 & 55 & \\
\hline 7. $17 \beta(\mathrm{H}), 21 \beta(\mathrm{H})$-trishomohopan-32-one & 468 & 247 & \\
\hline 8. octatriaconta-16(E),23(E)-dien-3-one & 544 & 55 & \\
\hline 9. octatriaconta-16(E),23(E)-dien-2-one & 544 & 55 & \\
\hline 10. nonatriaconta-10(E),17(E),24(E)-trien-3-one & 556 & 55 & \\
\hline 11. nonatriaconta-17(E),24(E)-dien-3-one & 558 & 55 & \\
\hline 12. cluster of $\mathrm{C}_{40}$ saturated wax esters & 592 & 57 & \\
\hline
\end{tabular}

*See Appendix for molecular structures.

**Tentative identification.

origin. More specifically, dinoflagellates are a likely source for the 4-methyl steroid ketones (e.g., Brassell et al., 1983).

Several compounds having an ester group have been observed, of which $17 \beta(\mathrm{H}), 21 \beta(\mathrm{H})$-hopan-30-oic acid methyl ester $(2 ; \mathrm{XV})$, a cluster of $\mathrm{C}_{40}(12)$, and a cluster of putative diunsaturated $\mathrm{C}_{38}$ wax esters are most abundant among the GC amenable esters. We cannot exclude the possibility that the hopanoid ester is an artifact of our work-up procedure, during which we applied methanol. Thus, the mode of occurrence of this compound may be that of an acid. The mass spectrum of the cluster of $\mathrm{C}_{40}$ wax esters (12) is almost identical to that published by Boon and de Leeuw (1979). We conclude from the intensity distribution of typical fragment ions that a $\mathrm{C}_{40}$ wax ester (XII) having a $\mathrm{C}_{16}$ fatty acid and $\mathrm{C}_{24}$ alcohol moiety is the most important isomer. Although the capillary column used for GC analysis was not ideally suited for analyzing wax esters, clearly the distribution in sediments differed from the distribution in particulate matter from the

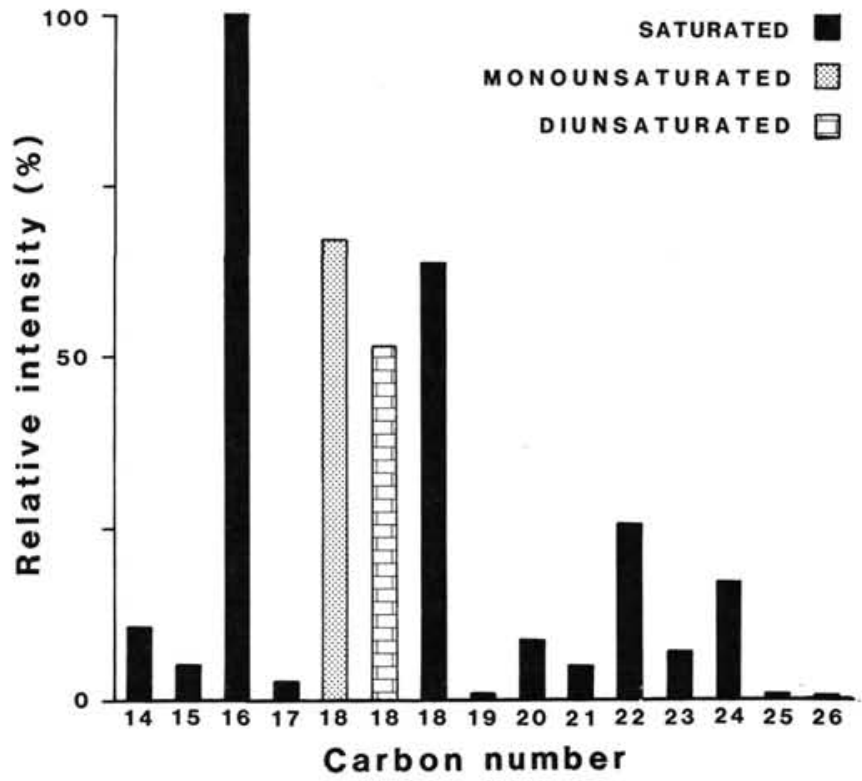

Figure 9. Bar graph showing the distribution of saturated and unsaturated straight-chain fatty acids obtained after saponification of the ketone plus ester fraction of Sample 112-679C-1H-1, 30-37 cm

water column, as reported by Wakeham (1985) and Wakeham et al. (1983). In particulate matter off the coast of Peru, wax esters maximize either at $\mathrm{C}_{30}, \mathrm{C}_{32}$, or $\mathrm{C}_{34}$, whereas in the studied sediment the maximum is at $\mathrm{C}_{38}$ or $\mathrm{C}_{40}$. This latter distribution is similar that reported by Boon and de Leeuw (1979) for sediments deposited under the upwelling cell of Walvis Bay.

To substantiate the tentative identification of a diunsaturated $\mathrm{C}_{38}$ wax ester (5) and to look for the presence of steryl esters, which are not GC amenable, the ketone plus ester fraction of Sample 112-679C-1H-1, 30-37 cm, was saponified with $\mathrm{KOH}$ under reflux. The resultant extract was separated by MPLC into a ketone, an alcohol, and an acid fraction, all of which were analyzed by GC and GC-MS after appropriate derivatization. The distribution of the ester-bound fatty acids is given in Figure 9. The $C_{16}$ saturated fatty acid is the most abundant acid, followed by a saturated, a monounsaturated, and a diunsaturated $\mathrm{C}_{18}$ fatty acid. No isoprenoid acids were observed. The highest homolog is the $\mathrm{C}_{26}$ fatty acid, which agrees well with the maximum chain length of the acid moiety of wax esters, as determined by Boon and de Leeuw (1979). The presence of an abundant $\mathrm{C}_{18}$ diunsaturated fatty acid corroborates to some extent our identification of the diunsaturated $\mathrm{C}_{38}$ wax ester. However, one must keep in mind that a large part of the fatty acids may come from steryl esters, which can, for instance, have a $\mathrm{C}_{16}$ acid moiety (e.g., Brassell et al., 1983).

The ester-bound alcohol fraction contains a series of saturated straight-chain alcohols $\left(\mathrm{C}_{14}-\mathrm{C}_{28}\right)$ and a variety of sterols. The $\mathrm{C}_{16}$ and $\mathrm{C}_{18}$ members are the most important compounds among the n-alkanols, but are unimportant in comparison with sterols. The maximum chain length $\left(\mathrm{C}_{28}\right)$ is in accordance with the maximum chain length of the alcohol moiety of wax esters, as determined by Boon and de Leeuw (1979). The sterols have a variety of carbon skeletons $\left(\mathrm{C}_{26}-\mathrm{C}_{30}\right)$, with various levels of unsaturation and almost exclusively without alkylation at C-4. A partial gas chromatogram showing the distribution of bound alcohols is given in Figure 10, and the identified peaks are listed in Table 8 . Cholesta-5,22-dien-3 $\beta$-ol $(10 ; \mathrm{XVI})$, cholest5 -en-3 $\beta$-ol (13) and 24 -ethylcholest-5-en-3 $\beta$-ol (26; XVII) are 


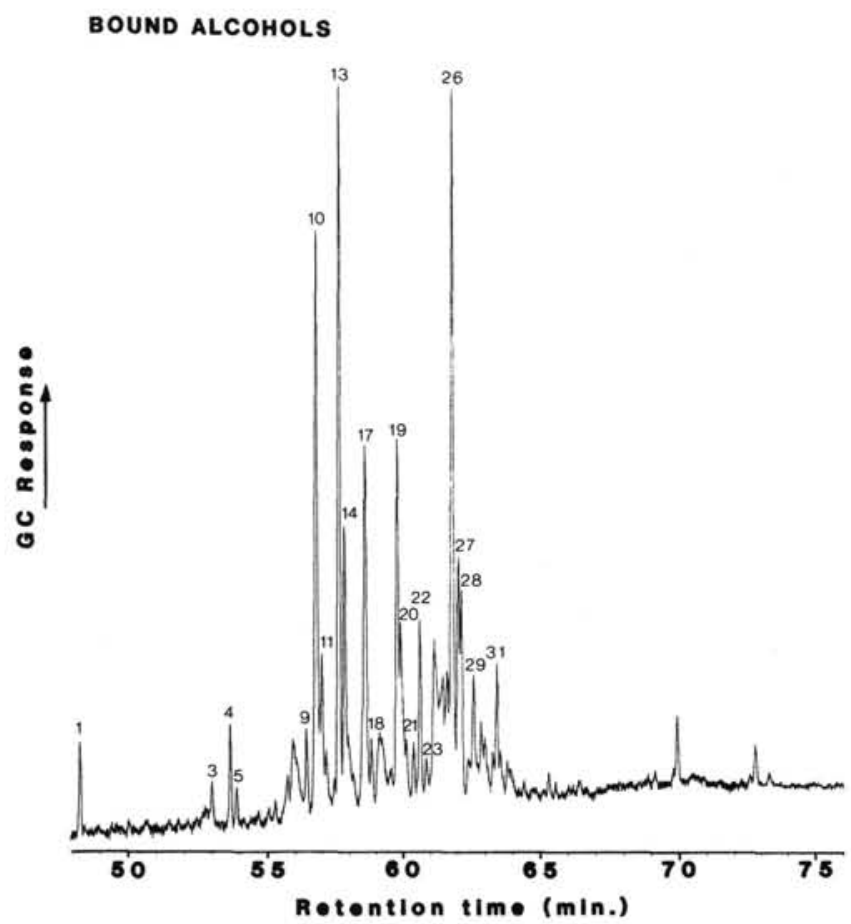

Figure 10. Partial gas chromatogram of the ester-bound alcohol fraction of Sample 112-679C-1H-1, 30-37 cm. Identification of numbered compounds is given in Table 8 .

the most important compounds of the bound alcohol fraction. Only one 4-methyl sterol was found ( $4 \alpha, 23,24$-trimethylcholest-22-en-3 $\beta$-ol;29; XVIII). A comparison of our results with those obtained from lacustrine sediments by Cranwell and Volkman (1981) shows that $\mathrm{C}_{27}$ sterols are much more abundant here, which we interpret as indicative of a marine origin for the sterol esters. There are, however, no published reports on the distribution of sterol esters in the Peru upwelling area. The dominance of ester-bound sterols over ester-bound straight-chain alcohols indicates that either sterol esters are more important than wax esters, or they are more resistant to degradation and, hence, enriched in relative quantities. However, this latter suggestion conflicts with the observation of de Leeuw et al. (1977) that sterol esters are rapidly hydrolyzed during early diagenesis.

\section{Alcohol Fraction}

Before discussing this fraction, we should mention that a comparison of the alcohols encountered in the alcohol fraction with those in the total lipid fraction revealed that alkan15-on-1-ols were not recovered completely and that alkandiols were totally lost during the MPLC separation (see discussion of total lipid fraction). No apparent loss was observed for other alcohols discussed hereafter.

Partial gas chromatograms of the free-alcohol fraction of two representative samples are shown in Figure 11. A wide variety of sterols was identified (Table 8), including relatively rare sterols such as $5 \beta(\mathrm{H})$-cholestan- $3 \beta$-ol $(7 ; \mathrm{XIX}), 5 \beta(\mathrm{H})$ cholestan-3 $\alpha$-ol $(8)$, and $5 \alpha(\mathrm{H})$-cholestan- $3 \alpha-\mathrm{ol}(15 ; \mathrm{XX})$. One compound had mass fragmental characteristics (Fig. 7C), which are consistent with the trimethylsilyl ether of 24 nor- $5 \alpha(\mathrm{H})$-cholestan-3 $\beta$-ol $(6 ; \mathrm{XXI})$. Traces of $\Delta^{7}$ sterols were also noted. The $4 \alpha, 23,24$-trimethylcholest-22-en-3 $\beta$-ol (29; $\mathrm{XVIII)}$ is the dominating sterol in most samples, although sometimes 24 -ethylcholest-5-en-3 $\beta$-ol $(26, \mathrm{XVII})$ or the tentatively identified 24 -propyl- $5 \alpha(\mathrm{H})$-cholestan-3 $\beta$-ol (32) occur as
Table 8. Alcohols identified as TMS-ethers in the bound-alcohol fraction (Fig. 10) and the free-alcohol fraction (Fig. 11).

\begin{tabular}{|c|c|c|c|}
\hline & $\mathbf{M +}$ & BP & Structure* \\
\hline 1. tetracosanol & 426 & 411 & \\
\hline 2. pentacosanol & 440 & 425 & \\
\hline 3. hexacosanol & 454 & 439 & \\
\hline 4. 24-norcholesta-5,22-dien-3 $\beta$-ol & 442 & 97 & \\
\hline 5. 24 -nor- $5 \beta(\mathrm{H})$-cholest- 22 -en- $3 \beta$-ol & 444 & 75 & \\
\hline 6. 24 -nor- $5 \alpha(\mathrm{H})$-cholestan-3 $\beta$-ol ${ }^{*}$ & 446 & 75 & XXI \\
\hline 7. $5 \beta(\mathrm{H})$-cholestan- $3 \beta-, \mathrm{OL}$ and & 460 & 370 & XIX \\
\hline heptacosanol & 468 & 453 & \\
\hline 8. $5 \beta(\mathrm{H})$-cholestan- $3 \alpha$-ol & 460 & 370 & \\
\hline $\begin{array}{l}\text { 9. 27-nor-24-methylcholesta- } \\
\text { 5,22-dien-3 } \beta \text {-ol }\end{array}$ & 456 & 111 & \\
\hline 10. cholesta-5,22-dien-3 $\beta$-ol & 456 & 129 & XVI \\
\hline 11. $5 \alpha(\mathrm{H})$-cholest-22-en-3 $\beta$-ol & 458 & 75 & \\
\hline 12. octacosanol & 482 & 467 & \\
\hline 13. cholest-5-en-3 $\beta$-ol & 458 & 129 & \\
\hline 14. $5 \alpha(\mathrm{H})$-cholestan-3 $\beta$-ol & 460 & 75 & \\
\hline 15. $5 \alpha(\mathrm{H})$-cholestan- $3 \alpha-\mathrm{ol}$ & 460 & 75 & $\mathrm{XX}$ \\
\hline 16. 24 -methyl- $5 \beta(\mathrm{H})$-cholestan-3 $\beta$-ol & 474 & 75 & \\
\hline 17. 24 -methylcholesta-5,22-dien-3 $\beta$-ol & 470 & 69 & \\
\hline 18. 24 -methyl- $5 \alpha(\mathrm{H})$-cholest-22-en-3 $\beta$-ol & 472 & 69 & \\
\hline $\begin{array}{l}\text { 19. 24-methylcholesta- } \\
5,24(28) \text {-dien-3 } \beta \text {-ol }\end{array}$ & 470 & 73 & \\
\hline 20. 24 -methylcholest-5-en-3 $\beta$-ol & 472 & 129 & \\
\hline 21. 24 -methyl- $5 \alpha(\mathrm{H})$-cholestan-3$\beta$-ol & 474 & 75 & \\
\hline 22. 24-ethylcholesta-5,22-dien-3 $\beta$-ol & 484 & 83 & \\
\hline 23. 24-ethyl- $5 \alpha(\mathrm{H})$-cholest-22-en-3 $\beta$-ol & 486 & 257 & \\
\hline 24. $4 \alpha, 24$-dimethyl-cholest-22-en-3 $\beta$-ol & 486 & 69 & \\
\hline 25. tricontanol & 510 & 495 & \\
\hline 26. 24-ethylcholest-5-en-3 $\beta$-ol & 486 & 129 & XVII \\
\hline 27. 24-ethyl-5 $\alpha(\mathrm{H})$-cholestan-3 $\beta$-ol & 488 & 75 & \\
\hline 28. 24 -ethylcholesta- $5,24(28)$-dien-3 $\beta$-ol & 484 & 73 & \\
\hline $\begin{array}{l}\text { 29. } 4 \alpha, 23,24 \text {-trimethyl- } \\
5 \alpha(\mathrm{H}) \text {-cholest-22-en-3 } \beta \text {-ol }\end{array}$ & 500 & 69 & XVIII \\
\hline 30. 24 -propylcholest- 5 -en-3 $\beta$-ol $* *$ & 500 & 73 & \\
\hline $\begin{array}{l}\text { 31. 24-propylcholesta- } \\
5,24(28) \text {-dien-3 } \beta \text {-ol }{ }^{* *}\end{array}$ & 498 & 69 & \\
\hline 32. 24-propyl-5 $\alpha(\mathrm{H})$-cholestan-3 $\beta$-ol $* *$ & 502 & 75 & \\
\hline $\begin{array}{l}\text { 33. two peaks: } 4 \alpha, 22,24 \text { - } \\
\text { trimethyl- } 5 \alpha(\mathrm{H}) \text {-cholestan-3 } 3 \text {-ol }\end{array}$ & 502 & 75 & \\
\hline $\begin{array}{l}\text { and/or } 4 \alpha, 23,24- \\
\text { trimethyl-5 } \alpha(\mathrm{H}) \text {-cholestan-3 } \beta \text {-ol }\end{array}$ & 502 & 75 & \\
\hline 34. triacontan-15-one-1-ol & 524 & 509 & \\
\hline 35. dotriaconten-15-one-1-ol** & 550 & 535 & \\
\hline 36. dotriacontan-15-one-1-ol & 552 & 537 & \\
\hline 37. tetratriacontan-15-one-1-ol & 590 & 575 & \\
\hline
\end{tabular}

*See Appendix for molecular structures.

***Tentative identification Table 9.

the most abundant compounds of this series. The $5 \alpha(\mathrm{H})$ stanols (e.g., 14, 21, 27) become more important with increasing burial depth. Dinoflagellates are the major source for the 4-methyl sterols (e.g., Boon et al., 1979; Robinson et al., 1984), and the feces and carcasses of fish and zooplankton for the cholest-5-en-3 $\beta$-ol (Gagosian et al., 1983a, 1983b). Typical diatom-derived sterols, like 24 -methylcholesta-5,22-dien-3 $\beta$ ol (17) and 24-methylcholesta-5,24(28)-dien-3 $\beta$-ol (19), also are present, although their relative abundance is not enhanced in samples having a high diatom content, observed under the microscope (Table 4). Sterol distribution is comparable to the distribution reported by Volkman et al. (1987), with the exception that dinosterol is relatively more enriched in the samples we have studied.

A significant difference can be observed in the abundance of $\mathrm{C}_{22}-\mathrm{C}_{28} n$-alkanols (Fig. 11). All four samples from the Pliocene section of Site 684 (Table 1) show this relative enrichment of continent-derived n-alkanols. An increased supply of wind-transported terrigenous organic matter to these four samples may be the reason for the high organiccarbon contents, which, as stated before, could not be attributed to an intensification of upwelling. 


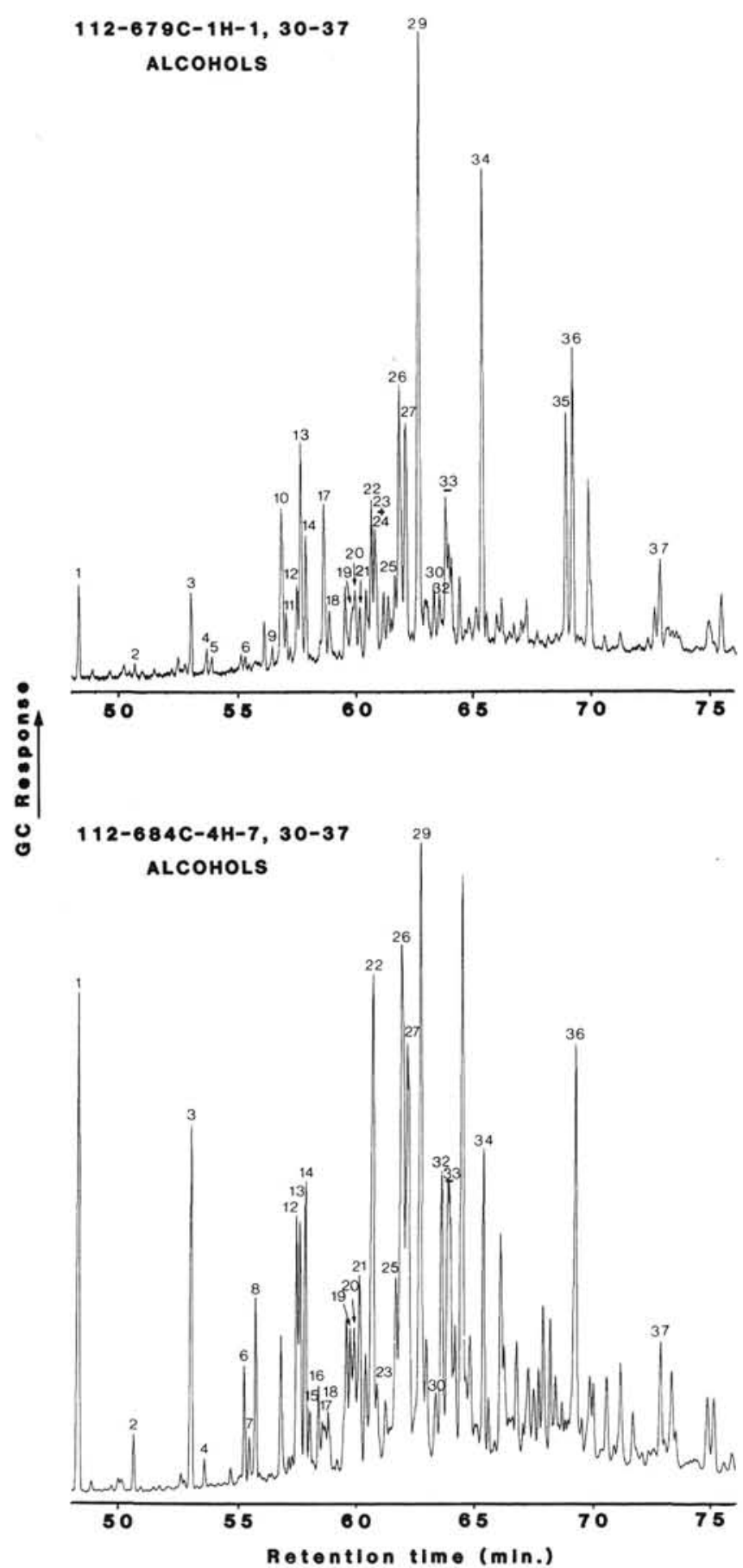

Figure 11. Partial gas chromatograms of the free alcohol fraction of Samples $112-679 \mathrm{C}-1 \mathrm{H}-1,30-37 \mathrm{~cm}$, and $-684 \mathrm{C}-4 \mathrm{H}-4,30-37 \mathrm{~cm}$. Identification of numbered compounds is given in Table 8.

The distribution of hopanoid alcohols, as shown by an $\mathrm{m} / \mathrm{z}$ 191 mass chromatogram, is similar to that reported by Volkman et al. (1987), i.e., a major $C_{30}$ hopanol occurs in addition to small amounts of homohopan-31-ol and bishomohopan32-ol. Volkman et al. (1987) tentatively identified this major compound as diplopterol, based on a mass spectrum of an acetate derivative. The mass spectrum that we obtained of the silylated compound is similar to that published by Venkatesan et al. (1987), who also ascribed the fragmentation as characteristic of diplopterol. However, we think this interpretation is erroneous because of the absence of the base peak fragment ion at m/z 131 [cleavage of side chain: ${ }^{+} \mathrm{CMe}_{2}\left(\mathrm{OSiMe}_{3}\right)$ ] (cf. Bisseret et al., 1985; Zundel and Rohmer, 1985; ten Haven et al., 1987). Recently, we have shown that this compound is in fact tetrahymanol, (ten Haven et al., 1989).

\section{Highly Polar Fraction}

Among the GC amenable compounds, loliolide (XXIII) and dihydroactinidiolide are important, next to several unknowns. Both are degradation products of carotenoids typically found in diatoms and dinoflagellates (Klok et al., 1984; Repeta and Gagosian, 1987).

\section{Total Lipid Fraction}

Partial gas chromatograms of the total lipid fraction of four samples are shown in Figure 12. In all samples, long-chain unsaturated ketones are the most important compounds (13, 14, 15; Table 9), even in sediments having a carbonate content of almost zero (Table 1). This latter observation may indicate that the calcareous nannoplankton Emiliania huxleyi is not a major contributor for this class of lipids in Peruvian sediments. The presence of $E$. huxleyi has been documented in today's Peru upwelling area, although its distribution is very patchy (Ryther et al., 1971). However, the age of most sediments investigated predates the first occurrence of $E$. huxleyi. Other algae from the class of Prymnesiophyte, including species not having formed coccoliths, are a more likely source for the long-chain ketones (cf. Marlowe et al., 1984). However, we cannot exclude that the calcareous nannoplankton record has been reduced by calcite dissolution and reprecipitation of dolomite.

The second mest abundant group of compounds is composed of $\mathrm{C}_{30^{-}}$and $\mathrm{C}_{32^{-}}$-alkandiols $(9,11)$, and $\mathrm{C}_{30^{-}}$and $\mathrm{C}_{32^{-}}$ alkan-15-on-1-ols $(10,12)$. The 1,15 -diol is the most important $\mathrm{C}_{30}$ member and the 1,13-diol the most important $\mathrm{C}_{32}$ member of the diols. The planktonic cyanobacterium Aphemizomenon flos-aquae may be a potential biological source (Morris and Brassell, 1988), but other sources cannot be excluded at present. Surprisingly, these compounds were not detected during the detailed studies of Smith and his coworkers (Smith, 1984; Smith et al., 1982, 1983a, 1983b, 1983c), despite their apparent abundance in Peruvian sediments (cf., Farrimond et al., this volume; Volkman et al., 1987). Other important compounds are sterols and, in some samples, $n$-alkanols, of which the details have already been discussed.

\section{CONCLUSIONS}

Drilling on the continental margin off Peru confirms that preservation of organic matter in deep-sea sediments is favored in areas of coastal upwelling. Although from the analysis of samples from only three sites one cannot expect the appropriate regional coverage, some distinct trends are obvious. Coastal upwelling at Site 679 apparently was strong during the Quaternary. However, mass accumulation rates of organic matter, in contrast to our expectations, were not higher than those in the Northwest African upwelling area. Values for the Peru margin may have to be revised toward higher accumulation rates when more precise sedimentation rates become available for this time interval. High organiccarbon contents in the early Pliocene at the same site coincide with low sedimentation rates and, thus, cannot be related to high surface-water bioproductivity in an upwelling cell. Although hard to imagine at present from a regional topography standpoint, reduced circulation of water masses may have been responsible for higher organic-carbon preservation during the early Pliocene at Sites 679. On the other hand, the 

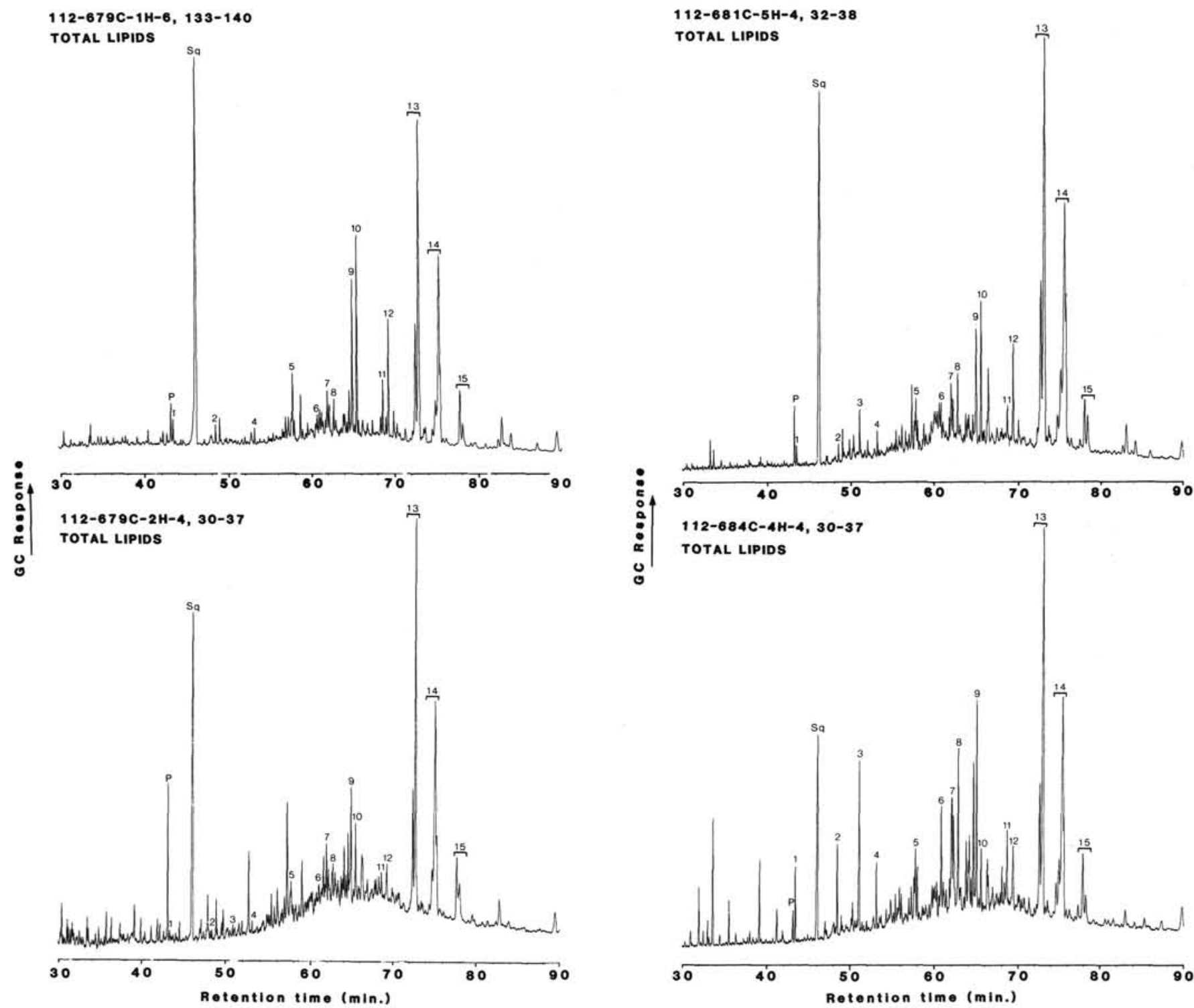

Figure 12. Partial gas chromatograms of the total lipid fraction of Samples $112-679 \mathrm{C}-1 \mathrm{H}-6,133-140 \mathrm{~cm},-679 \mathrm{C}-2 \mathrm{H}-4,30-37 \mathrm{~cm},-681 \mathrm{C}-5 \mathrm{H}-4$, $32-38 \mathrm{~cm}$, and $-684 \mathrm{C}-4 \mathrm{H}-4,30-37 \mathrm{~cm}$. The amount of internal standard relative to weight of organic extract (squalane, indicated by Sq) is the same in all samples. Contamination by phtalate esters is indicated by P. Identification of numbered compounds is given in Table 9 .

slope basin setting of Site 684 together with the strong increase of interstitial salts observed at this site (Suess, von Huene, et al., 1988; Site 684 Chapter) provide the possibility that a density stratification of the water column during Pliocene time led to a stagnant anoxic bottom water mass, which was then responsible for enhanced rates of organicmatter preservation.

The unusually small particle sizes of the organic matter in the Peru margin sediments indicate that fecal pellets, i.e., reworking in the food web, as well as anaerobic bacterial reworking and bacterial bioproductivity in surface sediments have a major influence on the organic facies. Molecular organic geochemical data on the extractable lipids confirm that marine planktonic organisms and bacteria are the main contributors to the sedimentary organic matter. Terrigenous material is subordinate, but over-represented among the larger macerals and in the nonaromatic hydrocarbon fractions (long-chain $n$-alkanes). Complexity of the preservation and transformation processes in the water column and in the sediment succession is reflected by lack of correlation between our data and published information on surface sediments and sediment trap material. Despite the details of the molecular composition of many compound classes documented in this study, any detailed conclusions may be premature. Several new compounds so far not reported in sediments were (tentatively) identified. The low relative abundance of organic sulfur compounds cannot be easily correlated with their significantly higher abundance in other organic-matter-rich deep-sea sediments. Particular emphasis will have to be placed on the relationship between the molecular composition of the extractable material and the distinct mode of occurrence of organic matter in the Peru margin sediments, i.e., this organic matter is finely disseminated and so closely mixed with the mineral matrix to the extent that the latter is even largely protected from destruction by strong mineral acids. 
Table 9. Selected compounds identified in the total lipid fraction (Fig. 12).

\begin{tabular}{|c|c|}
\hline Compound & Structure* \\
\hline \multicolumn{2}{|l|}{ 1. docosanol } \\
\hline $\begin{array}{l}\text { 2. tetracosanol } \\
\text { 3. perylene }\end{array}$ & \\
\hline \multicolumn{2}{|l|}{$\begin{array}{l}\text { 3. perylene } \\
\text { 4. hexacosanol }\end{array}$} \\
\hline \multicolumn{2}{|l|}{ 5. cholest- 5 -en- $3 \beta$-ol } \\
\hline \multicolumn{2}{|l|}{ 6. 24-ethylcholest-5,22-dien-3 $\beta$-ol } \\
\hline 7. 24-ethylcholest-5-en-3 $\beta$-ol & XVII \\
\hline 8. $4 \alpha, 23,24$-trimethylcholest-22-en-3 $\beta$-ol & XVIII \\
\hline 9. triacontan-1,15-diol (also 1,13 and 1,14-diols) & \\
\hline \multicolumn{2}{|l|}{ 10. triacontan-15-one-1-ol } \\
\hline \multirow{2}{*}{\multicolumn{2}{|c|}{$\begin{array}{l}\text { 11. dotriacontan-1,13-diol (also } 1,14 \text { and 1,15-diols) } \\
\text { 12. dotriacontan-15-one-1-ol }\end{array}$}} \\
\hline & \\
\hline 13. $C_{37}$ unsaturated ketones & e.g., XI \\
\hline 14. $C_{38}$ unsaturated ketones & \\
\hline 15. $\mathrm{C}_{39}$ unsaturated ketones & \\
\hline
\end{tabular}

*See Appendix for molecular structures.

\section{ACKNOWLEDGMENTS}

Samples were obtained through the assistance of the international Ocean Drilling Program. We thank M. Radke and R. G. Schaefer for providing laboratory facilities and many persons from our technical staff for analytical support. This research was financially supported by the Deutsche Forschungsgemeinschaft (Bonn), grants We 346/27 and Ste $412 / 1$.

\section{REFERENCES}

Bisseret, P., Zundel, M., and Rohmer, M., 1985. Prokaryotic triterpenoids. 2. $2 \beta$-methyl hopanoids from Methylobacterium organophilum and Nostoc muscorum, a new series of prokaryotic triterpenoids. Eur. J. Biochem., 150:29-34.

Boon, J. J., and de Leeuw, J. W., 1979. The analysis of wax esters, very long mid-chain ketones and steryl-ethers isolated from Walvis Bay diatomaceous ooze. Mar. Chem., 7:117-132.

Boon, J. J., Rijpstra, W.I.C., de Lange, F., de Leeuw, J. W., Yoshioka, M., and Shimuzu, Y., 1979. Black Sea sterol-a molecular fossil for dinoflagellate blooms. Nature, 277:125-127.

Brassell, S. C., Wardroper, A.M.K., Thomson, I. D., Maxwell, J. R., and Eglinton, G., 1981. Specific acyclic isoprenoids as biological markers of methanogenic bacteria in marine sediments. Nature, 290:693-696.

Brassell, S. C., Eglinton, G., and Maxwell, J. R., 1983. The geochemistry of terpenoids and steroids. Biochem. Soc. Trans., 11:575586.

Brassell, S. C., Lewis, C. A., de Leeuw, J. W., de Lange, F., and Sinninghe Damsté, J. S., 1986. Isoprenoid thiophenes: novel products of sediment diagenesis? Nature, 320:160-162.

Ciereszko, L. S., and Youngblood, W. W., 1971. n-Hexadecyl and n-octadecyl disulfides in "sediment" derived from the gorgonian Pseudoplexaura porosa (Houttuyn), Geochim. Cosmochim. Acta, 35:851-853.

Cooper, W. T., Heiman, A. S., and Yates, R. R., 1986. Early diagenesis of organic carbon in sediments from the Peruvian upwelling zone. In Sohn, M. L. (Ed.), Organic Marine Geochemistry. Am. Chem. Soc. Symp. Ser., 305:158-172.

Cranwell, P. A., and Volkman, J. K., 1981. Alkyl and steryl esters in a recent lacustrine sediment. Chem Geol., 32:29-43.

de Leeuw, J. W., Rijpstra, W.I.C., Boon, J. J., de Lange, F., and Schenck, P. A., 1977. The relationship between lipids from Fontinalis antipyretica, its detritus and the underlying sediment: the fate of wax esters and sterol esters. In Golterman, H. L. (Ed.), Interactions Between Sediments and Fresh Water: Den Haag (Junk B.V.), 141-147.

Demaison, G. J., and Moore, G. T., 1980. Anoxic environments and oil source bed genesis. Org. Geochem., 2:9-31.

Durand, B., 1980. Kerogen. Insoluble Organic Matter from Sedimentary Rocks: Paris (Editions Technip).

Eglinton, G., and Hamilton, R. J., 1963. The distribution of alkanes. In Swain, T. (Ed.), Chemical Plant Taxonomy: London (Academic Press), 187-208.
Farrington, J. W., Davis, A. C., Sulanowski, J., McCaffrey, M. A., McCarthy, M., Clifford, C. H., Dickinson, P., and Volkman, J. K., 1988. Biochemistry of lipids in surface sediments of the Peru upwelling area at $15^{\circ} \mathrm{S}$. In Mattavelli, L., and Novelli, L. (Eds.), Advances in Organic Geochemistry 1987. Org. Geochem., 13:607617.

Gagosian, R. B., Volkman, J. K., and Nigrelli, G. E., 1983a. The use of sediment traps to determine sterol sources in coastal sediments off Peru. In Bjorøy, M., et al. (Eds.), Advances in Organic Geochemistry 1981: Chichester (Wiley), 369-379.

Gagosian, R. B., Nigrelli, G. E., and Volkman, J. K., 1983b. Vertical transport and transformation of biogenic organic compounds from a sediment trap experiment off the coast of Peru. In Suess, E., and Thiede, J. (Eds.), Coastal Upwelling. Its Sediment Record, Part $A$ : New York (Plenum Press), 241-272.

Garrigues, D., Parlanti, E., Lapouyade, R., and Bellocq, J., 1988. Distribution of methylperylene isomers in selected sediments. Geochim. Cosmochim. Acta, 52:901-907.

Gschwend, D. M., Chen, P. H., and Hites, R. A., 1983. On the formation of perylene in recent sediments: kinetic models. Geochim. Cosmochim. Acta, 47:2115-2119.

Klok, J., Baas, M., Cox, H. C., de Leeuw, J. W., and Schenck, P. A., 1984. Loliolides and dihydroactinidiolide in a recent marine sediment probably indicate a major transformation pathway of carotenoids. Tetrahedron Lett., 25:5570-5580.

Littke, R., and Rullkötter, J., 1987. Mikroskopische und makroskopische Unterschiede zwischen Profilen unreifen und reifen Posidonienschiefer aus der Hilsmulde. Facies, 17:171-180.

Littke, R., Baker, D. R., and Leythaeuser, D., 1988. Microscopic and sedimentologic evidence for the generation and migration of hydrocarbons in Toarcian source rocks of different maturities. In Mattavelli, L., and Novelli, L. (Eds.), Advances in Organic Geochemistry 1987. Org. Geochem., 13:549-559.

Marlowe, I. T., Brassell, S. C., Eglinton, G., and Green, J. C., 1984. Long-chain unsaturated ketones and esters in living algae and marine sediments. In Schenck, P. A., de Leeuw, J. W., and Lijmbach, G.W.M. (Eds.), Advances in Organic Geochemistry 1983. Org. Geochem., 6:135-141.

Morris, R. J., and Brassell, S. C., 1988. Long-chain alkanediols: biological markers for cyanobacterial contributions to sediments. Lipids, 23:256-258.

Nichols, P. D., Volkman, J. K., Palmisano, A. C., Smith, G. A., and White, D. C., 1988. Occurrence of an isoprenoid $C_{25}$ diunsaturated alkene and high neutral lipid content in antarctic sea-ice diatom communities. J. Phycol., 24:90-96.

Ourisson, G., Albrecht, P., and Rohmer, M., 1984. The microbial origin of fossil fuels. Sci. Am., 251:34-41.

Parrish, J. T., 1982. Upwelling and petroleum source beds, with reference to Paleozoic. AAPG. Bull., 66:750-774.

Reimers, C. E., and Suess, E., 1983. Spatial and temporal patterns of organic matter accumulation on the Peru continental margin. In Thiede, J., and Suess, E. (Eds.), Coastal Upwelling. Its Sediment Record, Part B: New York (Plenum Press), 311-345.

Repeta, D. J., 1989. Carotenoid diagenesis in recent marine sediments: II. Degradation of fucoxanthin to loliolide. Geochim. Cosmochim. Acta, 53:699-707.

Repeta, D. J., and Gagosian, R. B., 1983. Carotenoid transformation products in the upwelled waters off the Peruvian coast: suspended particulate matter, sediment trap material and zooplankton fecal pellet analyses. In Bjorøy, M., et al. (Eds.), Advances in Organic Geochemistry 1981: Chichester (Wiley), $380-388$.

Repeta, D. J., and Gagosian, R. B., 1984. Transformation and recycling of carotenoids and chlorins in the Peru upwelling region $\left(15^{\circ} \mathrm{S}, 75^{\circ} \mathrm{W}\right)$. Geochim Cosmochim Acta, 48:1265-1277.

1987. Carotenoid diagenesis in recent marine sediments: I. The Peru continental shelf $\left(15^{\circ} \mathrm{S}, 75^{\circ} \mathrm{W}\right)$. Geochim. Cosmochim. Acta, 51:1001-1009.

Robinson, N., Eglinton, G., Brassell, S. C., and Cranwell, P. A., 1984. Dinoflagellate origin for sedimentary $4 \alpha$-methyl steroids and $5 \alpha(\mathrm{H})$-stanols. Nature, 308:439-441.

Rullkötter, J., Mukhopadhyay, P. K., and Welte, D. H., 1984. Geochemistry and petrography of organic matter in sediments from Hole 530A, Angola Basin, and Hole 532, Walvis Ridge, Deep 
Sea Drilling Project. In Hay, W. W., Sibuet, J.-C., et al., Init Repts. DSDP, 75: Washington (U. S. Govt. Printing Office), 1069-1087.

Rullkötter, J., Landgraf, M., and Disko, U., 1988. Gas chromatographic and mass spectrometric characterization of isomeric alkylthiophenes $\left(\mathrm{C}_{20}\right)$ and their occurrence in deep sea sediments. $J$. High Res. Chrom. Comm., 11:633-638.

Rullkötter, J., Sinninghe Damsté, J. S., ten Haven, H. L., and de Leeuw, J. W., in press. Distribution of organic sulfur compounds in Mesozoic and Cenozoic deep sea sediments from the Atlantic and Pacific Oceans and the Gulf of California. In Orr, W., and White, C. M. (Eds.), Organic Sulfur in the Geosphere. Am. Chem. Soc. Symp. Ser.

Ryther, J. H., Menzel, D. W., Hulbert, E. M., Lorenzen, C. J., and Corwin N. 1971. The production and utilization of organic matter in the Peru coastal current. Invest. Pesq., 35:43-59.

Sinninghe Damsté, J. S., van Koert, E. R., Kock-van Dalen, A. C., de Leeuw, J. W., and Schenck, P. A., 1989. Characterization of highly branched isoprenoid thiophenes occurring in sediments and crude oils. Org. Geochem., 14:555-567.

Smith, D. J., 1984. Biochemistry of lipids in recent organic rich marine sediments [PhD dissert.]. University of Bristol.

Smith, D. J., Eglinton, G., Morris, R. J., and Poutanen, E. L., 1982. Aspects of the steroid geochemistry of an interfacial sediment from the Peruvian upwelling. Oceanol. Acta, 6:211-219.

Smith, D. J., Eglinton, G., and Morris, R. J., 1983a. Interfacial sediment and assessment of organic input from a highly productive water column. Nature, 305:259-263.

1983b. The lipid geochemistry of an interfacial sediment from the Peru continental shelf: fatty acids, alcohols, aliphatic ketones and hydrocarbons. Geochim. Cosmochim. Acta, 47:22252232.

1983c. Occurrence of long-chain alkan-diols and alkan15-one-1-ols in a Quaternary sapropel from the eastern Mediterranean. Lipids, 18:902-905.

Staresinic, N., Farrington, J., Gagosian, R. B., Clifford, C. H., and Hulburt, E. M., 1983. Downward transport of particulate matter in the Peru coastal upwelling; role of the anchoveta, Engraulis ringens. In Suess, E., and Thiede, J. (Eds.), Coastal Upwelling: Its Sediment Record, Part A: New York (Plenum Press), 225-240.

Stein, R., 1986. Organic carbon and sedimentation rate-further evidence for anoxic deep-water conditions in the Cenomanian/ Turonian Atlantic Ocean. Mar. Geol., 72:199-209.

Stein, R., Rullkötter, J., and Welte, D. H., 1986. Accumulation of organic-carbon-rich sediments in the late Jurassic and Cretaceous Atlantic Ocean-A synthesis. Chem. Geol., 56:1-32.

Stein, R., Rullkötter, J., Littke, R., Schaefer, R. G., and Welte, D. H., 1988. Organofacies reconstruction and lipid geochemistry of sediments from the Galicia margin, northeast Atlantic (ODP Leg 103). In Boillot, G., Winterer, E. L., et al., Proc. ODP, Sci. Results, 103: College Station, TX (Ocean Drilling Program), 567-585.

Stein, R., ten Haven, H. L., Littke, R., Rullkötter, J., and Welte, D. H., in press. Accumulation of marine and terrigenous organic matter at upwelling Site 658 and nonupwelling Sites 657 and 659: Implications for the reconstruction of paleoenvironments in the eastern subtropical Atlantic through late Cenozoic time. In Ruddiman, W., Sarnthein, M., et al., Proc. ODP, Sci. Results, 108: College Station, TX (Ocean Drilling Program).

Suess, E., Kulm, L. D., and Killingley, J. S., 1987. Coastal upwelling and a history of organic-rich mudstone deposition off Peru. In Brooks, J., and Fleet, A. J. (Eds.), Marine Petroleum Source Rocks. Geol. Soc. Spec. Publ., 26:181-197.
Suess, E., von Huene, R., et al., 1988. Proc. ODP, Init. Repts., 112: College Station, TX (Ocean Drilling Program).

ten Haven, H. L., and Rullkötter, J., 1988. The diagenetic fate of taraxer-14-ene and oleanene isomers. Geochim. Cosmochim. Acta, 52:2543-2548.

ten Haven, H. L., Baas, M., de Leeuw, J. W., Maassen, J. M., and Schenck, P. A., 1987. Organic geochemical characteristics of sediments from the anoxic brine-filled Tyro basin (eastern Mediterranean). Org. Geochem., 12:605-611.

ten Haven, H. L., Rullkötter, J., and Stein, R., in press. Preliminary analysis of extractable lipids in sediments from the eastern north Atlantic (leg 108): A comparison of a coastal upwelling area (Site 658) with a nonupwelling area (Site 659). In Ruddiman, W., Sarnthein, M., et al., Proc. ODP, Sci. Results, 108: College Station, TX (Ocean Drilling Program).

ten Haven, H. L., Rohmer, M., Rullkötter, J., and Bisseret, P., 1989. Tetrahymanol, the most likely precursor of gammacerane, occurs ubiquitously in marine sediments. Geochim. Cosmochim. Acta 53:3073-3079.

Thiede, J., and Suess, E., 1983. Coastal Upwelling. Its Sediment Record, Part B: New York (Plenum Press).

van Andel, T. H., Heath, J. R., and Moore, T. C., 1975. Cenozoic history and paleoceanography of the central equatorial Pacific. Geol. Soc. Am. Mem., 140.

Venkatesan, M. I., Ruth, E., Steinberg, S., and Kaplan, I. R., 1987. Organic geochemistry of sediments from the continental margin off southern New England, U.S.A.-Part II. Lipids. Mar. Chem., 21:267-299.

Volkman, J. K., 1986. A review of sterol markers for marine and terrigenous organic matter. Org. Geochem., 9:83-99.

Volkman, J. K., Eglinton, G., Corner, C.D.S., and Sargent, J. R., 1980. Novel unsaturated straight-chain $\mathrm{C}_{37}-\mathrm{C}_{39}$ methyl and ethyl ketones in marine sediments and a coccolithophore Emiliania huxleyi. In Douglas, A. G., and Maxwell, J. R. (Eds.), Advances in Organic Geochemistry 1979: Oxford (Pergamon Press), 219-227.

Volkman, J. K., Farrington, J. W., Gagosian, R. B., and Wakeham, S. G., 1983. Lipid composition of coastal marine sediments from the Peru upwelling region. In Bjorøy, M., et al. (Eds.), Advances in Organic Geochemistry 1981: Chichester (Wiley), 228-240.

Volkman, J. K., Farrington, J. W., and Gagosian, R. B., 1987. Marine and terrigenous lipids in coastal sediments from the Peru upwelling region at $15^{\circ} \mathrm{S}$ : Sterols and triterpene alcohols. Org. Geochem., 11:463-477.

Wakeham, S. G., 1985. Wax esters and triacylglycerols in sinking particulate matter in the Peru upwelling area $\left(15^{\circ} \mathrm{S}, 75^{\circ} \mathrm{W}\right) . \mathrm{Mar}$. Chem., 17:213-235.

Wakeham, S. G., Farrington, J. W., and Volkman, J. K., 1983. Fatty acids, wax esters, triacylglycerols and alkyldiaglycerols associated with particles collected in sediment traps in the Peru upwelling. In Bjorøy, M., et al. (Eds.), Advances in Organic Geochemistry 1981: Chichester (Wiley), 185-197.

Wakeham, S. G., Farrington, J. W., and Gagosian, R. B., 1984. Variability in lipid flux and composition of particulate matter in the Peru upwelling region. In Schenck, P. A., de Leeuw, J. W., and Lijmbach, G.W.M. (Eds.), Advances in Organic Geochemistry 1983. Org. Geochem., 13:203-215.

Zundel, M., and Rohmer, M., 1985. Prokaryotic triterpenoids. 1. $3 \beta$-methylhopanoids from Acetobacter species and Methylococcus capsulatus. Eur. J. Biochem., 150:23-27.

Date of initial receipt: 13 December 1988

Date of acceptance: 5 July 1989

Ms 112B-160 


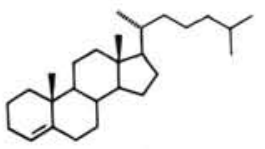

I. STER-4-ENE

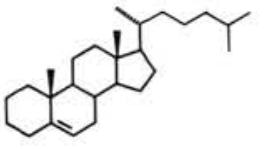

II. STER-5-ENE

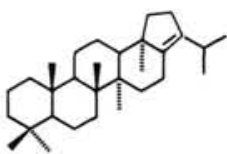

III. HOP-17(21)-ENE

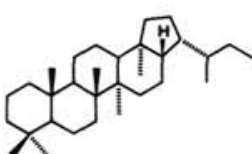

IV. $17 \beta(H), 21 \beta(H)-$ HOMOHOPANE<smiles>Cc1c2c(cc3c1CC[C@]31CCCC1C(C)CCCC(C)C)CCCC2</smiles>

VII. ANTHRASTEROID<smiles>CC(C)CCCC(C)CCCC(C)CCCC(C)C</smiles>

VIII. 3-METHYL-2-(3,7,11TRIMETHYLDODECYL)-THIOPHEN

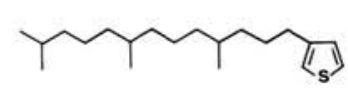

IX. 3-(4,8,12-TRIMETHYLTRIDECYL)-THIOPHENE

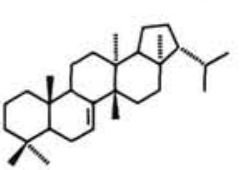

v. FERN-7-ENE

vi. Penylene<smiles>c1cc2cccc3c4cccc5cccc(c(c1)c23)c54</smiles>

X. 2,3-DIMETHYL-5-(7'(2', 6', 10', 14'-TETRAMETHYLPENTADECYL))-THIOPHENE

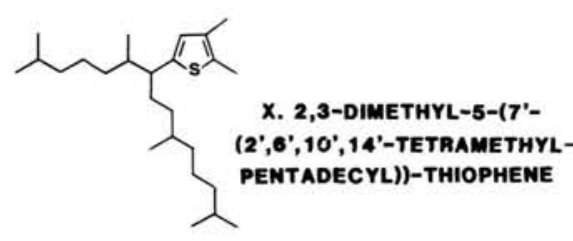

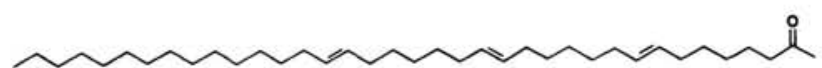

XI. HEPTATRIACONTA-8(E),15(E),22(E)-TRIEN-2-ONE

\section{(1)

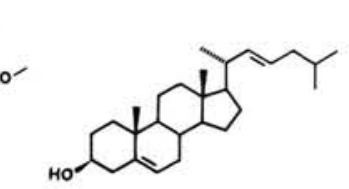

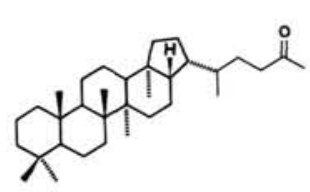

XIII. $17 \beta(H), 21 \beta(H)$-TRIS- XIV. $4 a, 23,24$-TRIMETHYL-

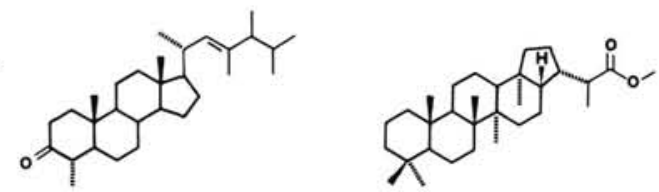

XV. $17 \beta(H), 21 \beta(H)-$ ?o<smiles>C1C[Te]1</smiles>

XII. TETRACOSANYL HEXADECANOATE (C24-C16 WAX ESTER)

XVI. CHOLESTA-5,22-

DIEN-3 $\beta$-OL

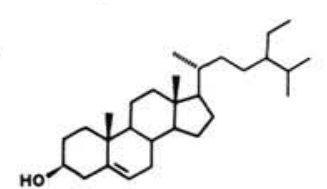

XVII. 24-ETHYLCHOLEST-5-EN-3 $\beta-O L$

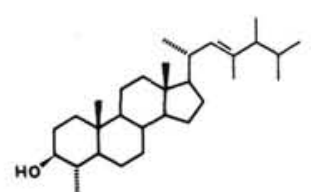

XVIII. 4a,23,24-TRIMETHYLCHOLEST-22-EN-3 $\beta$-OL

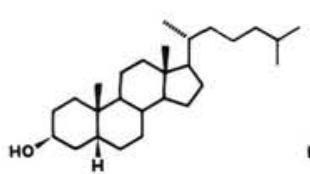

XIX. $5 \beta(\mathrm{H})-$ CHOLESTAN-3 $\beta$-OL<smiles>C=C(CCC(C)C)C(=O)C1CCC23CCCCC2CC1C3</smiles>

XX. $5 a(H)-$ CHOLESTAN-3a-OL

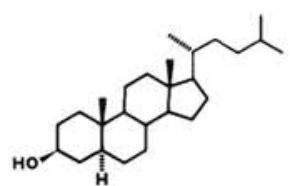

XXI. 24-NOR-5a(H)CHOLESTAN-3 $\beta$-OL

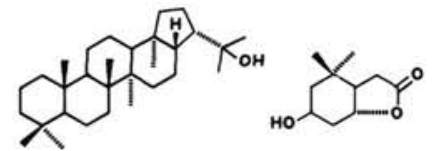

XXII. HOPAN-22-OL XXIII. LOLIOLIDE 